\title{
Distribution and genetic diversity of two earthworms, Helodrilus oculatus and Satchellius mammalis (Clitellata: Lumbricidae) in Scandinavia
}

\author{
Svante Martinsson', Mårten Klinth' and Christer Erséus'
}

\begin{abstract}
Martinsson S, Klinth M and Erséus C. 2021. Distribution and genetic diversity of two earthworms, Helodrilus oculatus and Satchellius mammalis (Clitellata: Lumbricidae) in Scandinavia. Fauna norvegica 41: 1-14.

We report on the Scandinavian distribution of two earthworm species, Helodrilus oculatus and Satchellius mammalis. Both appear relatively new to the Scandinavian Peninsula, as they were not included in the monographic revisions of the earthworm fauna of Sweden and Norway in the mid-1900s. We provide recent records of both species from Norway and Sweden, H. oculatus also from Denmark, and haplotype networks of four markers (COI, 16S, H3, and ITS2) are used to visualise the genetic diversity within each species. There is moderate genetic variation in COI for both taxa, and for H. oculatus, there is a West-East division between the specimens from Norway, Gothenburg (western Sweden) and Bavaria (Germany), and the ones from eastern Sweden and the Bornholm island (easternmost Denmark). This could potentially be explained by different origin and colonisation routes. In the other markers the variation is limited, and in the nuclear genes no pattern to support this split is seen. We also analyse the phylogenetic positions of $H$. oculatus and $S$. mammalis in the family Lumbricidae by combining our data (including also some $12 \mathrm{~S}, 18 \mathrm{~S}$ and $28 \mathrm{~S}$ sequences) with a published dataset. We conclude that neither Helodrilus nor Satchellius are monophyletic. Helodrilus oculatus (type species of Helodrilus), however, forms a clade with some of its current congeners.
\end{abstract}

doi: 10.5324/fn.v4li0.3874. Received: 2020-12-14. Accepted: 2021-02-26. Published online: 2021-05-27. ISSN: $1891-5396$ (electronic).

Keywords: DNA-barcoding, haplotype networks, phylogeny, Norway, Sweden

1. Systematics and Biodiversity, Department of Biological and Environmental Sciences, University of Gothenburg, Box 463, Göteborg SE-405 30, Sweden

Corresponding author: Christer Erséus

E-mail: christer.erseus@bioenv.gu.se

\section{INTRODUCTION}

The Scandinavian earthworm fauna consists of about 35 nominal species, all in the family Lumbricidae with the exception of a few introduced species, e.g., Amynthas corticis (Kinberg, 1867) (Megascolecidae) (Gates 1972) and two species of Dichogaster Beddard, 1888 (Acanthodrilidae)(Erséus et al. 1994), found in greenhouses or indoors in bathrooms. Two comprehensive studies of the Scandinavian earthworms were published by Stöp-Bowitz (1969) for Norway, and Julin (1949) for Sweden. There is also a newer checklist compiled by Blakemore (2007) available online, which lists 41 species from Denmark, Finland, Norway and Sweden.

In this paper we give several distributional records of two earthworms Helodrilus oculatus Hoffmeister, 1845 and Satchellius mammalis (Savigny, 1826) (Figure 1) in southern Scandinavia, supplemented by new records also from Germany and the Netherlands. Neither of these species were reported by Stöp-Bowitz (1969) or Julin (1949). Blakemore (2007) mentions H. oculatus from Denmark and S. mammalis from Denmark and Norway, and Sims and Gerard (1985) mentions S. mammalis from Norway, but this appears to be second-hand information without original (published) references. There are records of both species from Denmark (Møller et al. 2015).
Our limited samples revealed, for both species, a considerable level of variation in the $\mathrm{COI}$ barcoding gene, i.e., our primary marker for species recognition. To eliminate the possibility that cryptic species are involved, we herein also describe the genetic variation of the studied populations, by studying four different gene markers. Lastly, we analyse the phylogenetic position of these two taxa by adding them to a large dataset of DNA sequences of Lumbricidae studied by Domínguez et al. (2015).

The genus Helodrilus Hoffmeister, 1845 consists of about 20 described species and subspecies found from Morocco, the Iberian Peninsula, France, and the British Isles in the west to the Levant and Caucasus regions in the east (Szederjesi et al. 2014). Although only three species (and none of which is the type species, i.e., H. oculatus) were analysed by Domínguez et al. (2015), the latter authors found Helodrilus to be polyphyletic in their study. Representatives of this genus live mainly in moist soil and can be found in riverbanks, swamps and caves (Szederjesi et al. 2014). This is also true for $H$. oculatus, which can be found in running water, ditches, ponds, as well as in waterlogged soil, mainly in broadleaved woodlands (Sims \& Gerard 1985; Sherlock 2018).

Satchellius Gates, 1975 consists of only three species (Szederjesi 

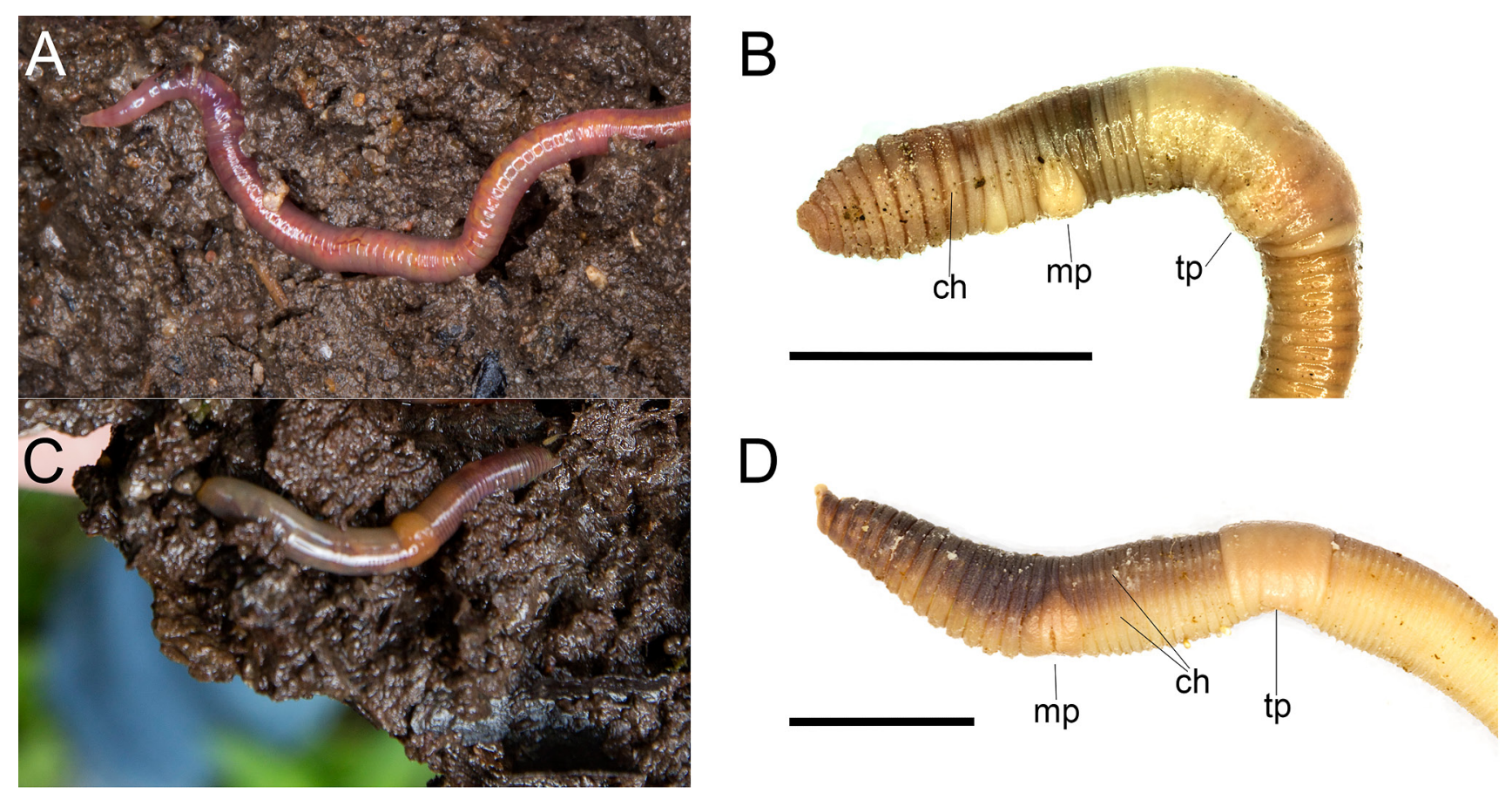

Figure I. Helodrilus oculatus (A-B) and Satchellius mammalis (C-D). A and C are live worms (Photo: Johan Wingborg); B and D worms preserved in ethanol (Photo: Svante Martinsson). A. Specimen from Vitsippsdalen, Gothenburg, Sweden; worm's anterior end was buried in the soil (outside the right edge of the photo). B. Specimen CE26263 from Tommarpsån River, Simrishamn, Sweden. C-D. Specimen CE26115 from Vitsippsdalen. Scale bars $=5 \mathrm{~mm}$; $\mathrm{ch}=$ chaetae, $\mathrm{mp}=$ male pore, $\mathrm{tp}=$ tuberculum pubertatis.

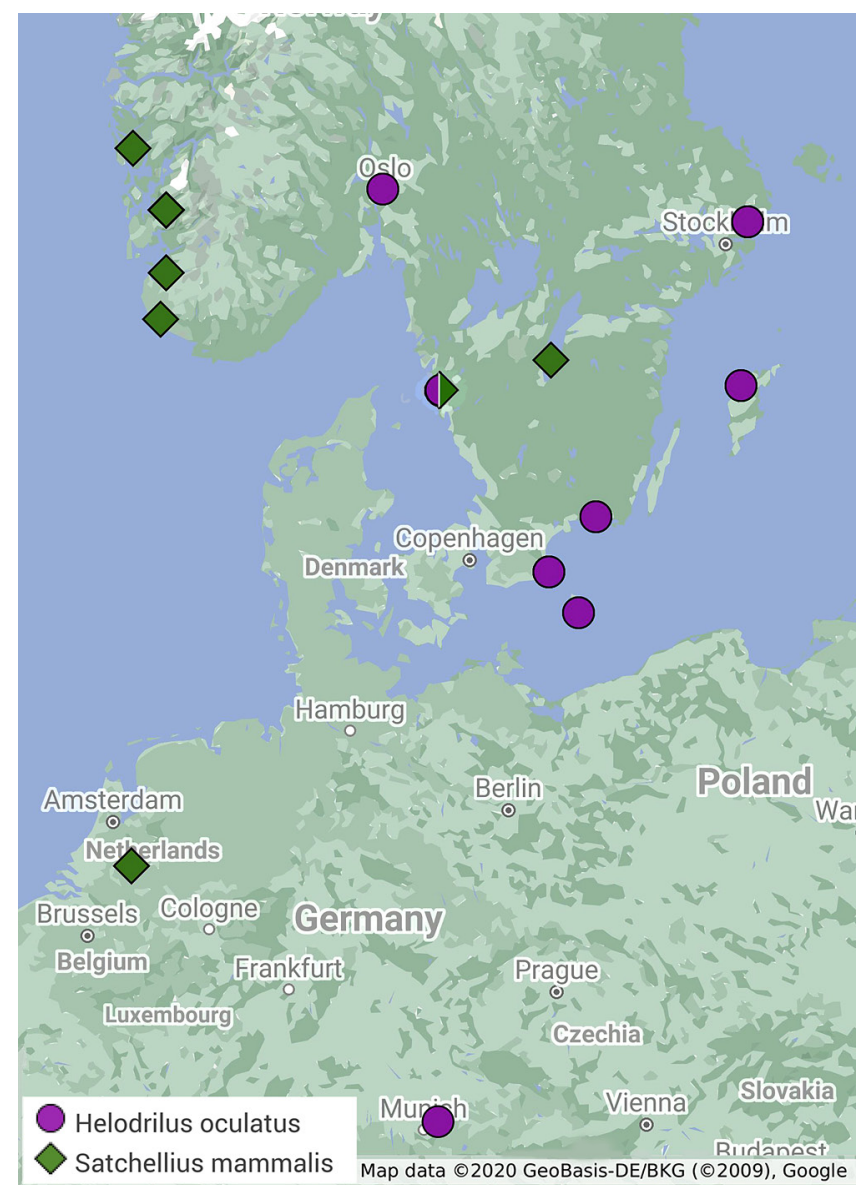

Figure 2. Distribution of Scandinavian specimens of Helodrilus oculatus and Satchellius mammalis used in this study. In Gothenburg (the locality shared between the two species) several closely situated sites are combined for clarity, see Appendix 1 for exact positions. The map is created in Google Maps and an interactive version of the map can be found at https:// www.google.com/maps/d/edit?mid=1mZbMePUxDLZZ4uQ-1XWp829LtgYU7ot\&usp=sharing.
\& Csuzdi 2016), all found on the Iberian peninsula, but the type species S. mammalis is found in several other W. European countries too (Sims \& Gerard 1985). Only one species was included in the lumbricid phylogeny by Domínguez et al. (2015), S. madeirensis (Michaelsen, 1891) as S. gatesi Qiu \& Bouché, 2000, the two taxa later synonymised by Szederjesi and Csuzdi (2016). Satchellius mammalis is mainly found in woodland in areas with high organic content, in old pastures and river banks (Sherlock 2018; Sims \& Gerard 1985).

\section{MATERIAL AND METHODS}

In total 39 specimens of Helodrilus oculatus ( 2 from Norway, 34 from Sweden, 2 from Denmark, and 1 from Germany), and 14 specimens of Satchellius mammalis (10 from Norway, 3 from Sweden and 1 from the Netherlands), collected between 2005 and 2017 were included in the study (Table 1; Appendix 1). The distribution of included individuals are visualised using Google Maps (Figure 2).

\section{DNA extraction and sequencing}

DNA was extracted from a small sample of the body wall taken from the posterior part of each specimen using either Qiagen DNeasy Blood \& Tissue Kit or Epicentre QuickExtract DNA Extraction Solution 1.0, following the manufacturer's instructions. The worms are stored in ethanol to serve as physical vouchers, and are deposited in either the Swedish Museum of Natural History (SMNH), Stockholm, Sweden, or the University Museum of Bergen (ZMBN), Bergen, Norway (accession numbers in Appendix 1).

For all specimens the mitochondrial Cytochrome c oxidase subunit I (COI) gene was amplified, and for a subset of worms the mitochondrial ribosomal $16 \mathrm{~S}$ gene, the complete nuclear ribosomal Internal Transcribed Spacer 2 (ITS2), and the nuclear gene Histone H3 (H3), were successfully amplified. The primers and PCR programmes used are listed in Table 2. For most specimens, all sequencing was carried out by Macrogen Inc. (Seoul, Korea) or Eurofins MWG 
Table I. Specimens of Helodrilus oculatus and Satchellius mammalis used in this study, with specimen ID:s, collection country and province, collection coordinates and GenBank Accession numbers. For more detailed collection information see Appendix 1. Note that for four specimens, three supplementary genes (12S, 18S, 28S) have been sequenced; their GenBank \#\# are given on inserted lines. In ITS2 and H3 some specimens are represented by two sequences as they are heterozygous.

\begin{tabular}{|c|c|c|c|c|c|c|c|c|c|}
\hline \multirow[b]{2}{*}{ Species } & \multirow[b]{2}{*}{ Specimen ID } & \multirow[b]{2}{*}{ Country Province } & \multicolumn{2}{|c|}{ Coordinates } & \multirow[b]{2}{*}{ BOLD } & \multicolumn{4}{|c|}{ GenBank Accession \# } \\
\hline & & & North & East & & $\mathrm{COI}$ & $16 \mathrm{~S}$ & ITS2 & $\mathrm{H} 3$ \\
\hline H. oculatus & CE1230 & SWE Västergötland & 57.6813 & 11.9562 & NVLUM001-21 & MW535839 & MW544108 & - & - \\
\hline H. oculatus & CE5690 & SWE Västergötland & 57.6817 & 11.9567 & NVLUM002-21 & MW535854 & MW544098 & $\begin{array}{l}\text { MW534290/ } \\
\text { MW534291 }\end{array}$ & MW542595 \\
\hline H. oculatus & CE5691 & SWE Västergötland & 57.6817 & 11.9567 & NVLUM003-21 & MW535835 & - & - & - \\
\hline H. oculatus & CE5692 & SWE Västergötland & 57.6817 & 11.9567 & NVLUM004-21 & MW535842 & - & - & $\begin{array}{l}\text { MW542596/ } \\
\text { MW542597 }\end{array}$ \\
\hline H. oculatus & CE5693 & SWE Västergötland & 57.6817 & 11.9567 & NVLUM005-21 & MW535846 & MW544103 & MW534292 & MW542610 \\
\hline H. oculatus & CE5694 & SWE Västergötland & 57.6817 & 11.9567 & NVLUM006-21 & MW535866 & MW544090 & MW534293 & MW542598 \\
\hline H. oculatus & CE5695 & SWE Västergötland & 57.6817 & 11.9567 & LUTCE188-10 & HQ573048 & - & - & - \\
\hline H. oculatus & CE5700 & SWE Västergötland & 57.6817 & 11.9567 & NVLUM007-21 & MW535862 & MW544093 & $\begin{array}{l}\text { MW534294/ } \\
\text { MW534295 }\end{array}$ & $\begin{array}{l}\text { MW542598/ } \\
\text { MW542600 }\end{array}$ \\
\hline H. oculatus & CE5705 & SWE Västergötland & 57.6817 & 11.9567 & NVLUM008-21 & MW535853 & - & - & - \\
\hline H. oculatus & CE7085 & SWE Västergötland & 57.6817 & 11.9567 & LUTCE478-10 & HQ989840 & - & - & - \\
\hline H. oculatus & CE7087 & SWE Västergötland & 57.6817 & 11.9567 & LUTCE479-10 & HQ989841 & - & - & - \\
\hline H. oculatus & CE6500 & SWE Uppland & 59.5710 & 18.5502 & NVLUM009-21 & MW535840 & MW544107 & $\begin{array}{l}\text { MW534296/ } \\
\text { MW534297 }\end{array}$ & MW542611 \\
\hline H. oculatus & CE6501 & SWE Uppland & 59.5710 & 18.5502 & LUTCE307-10 & HQ573155 & - & - & - \\
\hline H. oculatus & CE6502 & SWE Uppland & 59.5710 & 18.5502 & LUTCE308-10 & HQ573156 & - & - & - \\
\hline H. oculatus & CE6503 & SWE Uppland & 59.5710 & 18.5502 & LUTCE309-10 & HQ573157 & - & - & - \\
\hline H. oculatus & CE6504 & SWE Uppland & 59.5710 & 18.5502 & LUTCE310-10 & HQ989697 & - & - & - \\
\hline H. oculatus & CE6505 & SWE Uppland & 59.5710 & 18.5502 & NVLUM010-21 & MW535838 & MW544109 & MW534298 & $\begin{array}{l}\text { MW542601/ } \\
\text { MW542602 }\end{array}$ \\
\hline H. oculatus & CE8815 & GER, Bavaria & 48.2507 & 11.889 & LSWED290-11 & JN261155 & - & MW534299 & $\begin{array}{l}\text { MW542603/ } \\
\text { MW542604 }\end{array}$ \\
\hline H. oculatus & CE9307 & SWE, Gotland & 57.741 & 18.404 & LSWED412-11 & JN261264 & - & $\begin{array}{l}\text { MW534300/ } \\
\text { MW534301 }\end{array}$ & MW542605 \\
\hline H. oculatus & CE9308 & SWE, Gotland & 57.741 & 18.404 & LSWED413-11 & JN261265 & - & $\begin{array}{l}\text { MW534302/ } \\
\text { MW534303 }\end{array}$ & MW542607 \\
\hline H. oculatus & CE9311 & SWE, Gotland & 57.741 & 18.404 & LSWED414-11 & JN261266 & - & $\begin{array}{l}\text { MW534304/ } \\
\text { MW534305 }\end{array}$ & MW542606 \\
\hline H. oculatus & CE9732 & DEN, Bornholm & 55.0361 & 14.9092 & LSWED436-11 & JN261283 & - & $\begin{array}{l}\text { MW534288/ } \\
\text { MW534289 }\end{array}$ & $\begin{array}{l}\text { XX000000/ } \\
\text { MW542609 }\end{array}$ \\
\hline H. oculatus & CE9733 & DEN, Bornholm & 55.0361 & 14.9092 & LSWED437-11 & JN261284 & - & - & MW542608 \\
\hline H. oculatus & CE11347 & SWE Västergötland & 57.6847 & 11.9753 & NVLUM011-21 & MW535837 & MW544110 & $\begin{array}{l}\text { MW534306/ } \\
\text { MW534307 }\end{array}$ & MW542612 \\
\hline H. oculatus & CE11393 & SWE Västergötland & 57.6822 & 11.9551 & NVLUM012-21 & $\begin{array}{c}\text { MW535836 } \\
\text { 12S } \\
\text { MW538117 }\end{array}$ & $\begin{array}{c}\text { MW544111 } \\
\text { 18S } \\
\text { MW538113 }\end{array}$ & $\begin{array}{c}\text { MW534308/ } \\
\text { MW534309 } \\
\text { 28S } \\
\text { MW538298 }\end{array}$ & MW542613 \\
\hline H. oculatus & CE11468 & SWE Västergötland & 57.6822 & 11.9551 & NVLUM013-21 & MW535847 & - & - & - \\
\hline H. oculatus & CE11469 & SWE Västergötland & 57.6822 & 11.9551 & NOEAR057-18 & MW535874 & - & - & - \\
\hline H. oculatus & CE18776 & SWE Blekinge & 56.199 & 15.282 & NVLUM014-21 & MW535860 & MW544094 & $\begin{array}{l}\text { MW534310/ } \\
\text { MW534311 }\end{array}$ & MW542616 \\
\hline H. oculatus & CE18777 & SWE Blekinge & 56.199 & 15.282 & NVLUM015-21 & $\begin{array}{c}\text { MW535859 } \\
\text { 12S } \\
\text { MW538118 }\end{array}$ & $\begin{array}{c}\text { MW544095 } \\
\text { 18S } \\
\text { MW538116 }\end{array}$ & $\begin{array}{c}\text { MW534312/ } \\
\text { MW534313 } \\
\text { 28S } \\
\text { MW538299 }\end{array}$ & MW542617 \\
\hline H. oculatus & CE18778 & SWE Blekinge & 56.199 & 15.282 & NVLUM016-21 & MW535849 & MW544101 & $\begin{array}{l}\text { MW534314/ } \\
\text { MW534315 }\end{array}$ & MW542618 \\
\hline H. oculatus & CE18780 & SWE Blekinge & 56.199 & 15.282 & NOEAR084-18 & MW535850 & - & - & - \\
\hline H. oculatus & CE26114 & SWE Västergötland & 57.6807 & 11.9591 & NVLUM017-21 & MW535848 & MW544102 & $\begin{array}{l}\text { MW534316/ } \\
\text { MW534317 }\end{array}$ & MW542619 \\
\hline H. oculatus & CE26263 & SWE Skåne & 55.5321 & 14.2701 & NVLUM018-21 & MW535872 & MW544086 & MW534318 & MW542620 \\
\hline
\end{tabular}


Table I. Continued.

\begin{tabular}{|c|c|c|c|c|c|c|c|c|c|}
\hline \multirow[b]{2}{*}{ Species } & \multirow[b]{2}{*}{ Specimen ID } & \multirow[b]{2}{*}{ Country Province } & \multicolumn{2}{|c|}{ Coordinates } & \multirow[b]{2}{*}{ BOLD } & \multicolumn{4}{|c|}{ GenBank Accession \# } \\
\hline & & & North & East & & $\mathrm{COI}$ & $16 \mathrm{~S}$ & ITS2 & $\mathrm{H} 3$ \\
\hline H. oculatus & CE26264 & SWE Skåne & 55.5321 & 14.2701 & NVLUM019-21 & MW535851 & MW544100 & MW534319 & MW542621 \\
\hline H. oculatus & CE26265 & SWE Skåne & 55.5321 & 14.2701 & NVLUM020-21 & MW535841 & MW544106 & MW534320 & MW542622 \\
\hline H. oculatus & CE26266 & SWE Skåne & 55.5321 & 14.2701 & NOEAR121-18 & MW535858 & - & - & - \\
\hline H. oculatus & CE30992 & SWE Västergötland & 57.6864 & 11.9548 & NVLUM021-21 & MW535870 & MW544087 & $\begin{array}{l}\text { MW534321/ } \\
\text { MW534322 }\end{array}$ & MW542623 \\
\hline H. oculatus & CE16604 & NOR Oslo & 59.9281 & 10.7059 & NVLUM022-21 & MW535855 & MW544097 & MW534323 & MW542614 \\
\hline H. oculatus & CE16605 & NOR Oslo & 59.9281 & 10.7059 & NVLUM023-21 & MW535852 & MW544099 & $\begin{array}{l}\text { MW534324/ } \\
\text { MW534325 }\end{array}$ & MW542615 \\
\hline S. mammalis & CE4365 & SWE Småland & 58.0372 & 14.3127 & NVLUM024-21 & MW535873 & MW544085 & MW534331 & $\begin{array}{l}\text { MW542633/ } \\
\text { MW542634 }\end{array}$ \\
\hline S. mammalis & CE5391 & SWE Västergötland & 57.6850 & 11.8997 & NVLUM025-21 & MW535867 & MW544089 & $\begin{array}{l}\text { MW534333/ } \\
\text { MW534334 }\end{array}$ & MW542635 \\
\hline S. mammalis & CE26115 & SWE Västergötland & 57.6807 & 11.9591 & NVLUM026-21 & MW535863 & MW544092 & MW534327 & MW542632 \\
\hline S. mammalis & CE11843 & NOR Rogaland & 58.5021 & 5.9183 & NVLUM027-21 & MW535868 & MW544088 & MW534326 & MW542624 \\
\hline S. mammalis & CE12753 & NOR Hordaland & 60.3716 & 5.3325 & NOREW065-11 & MW535844 & - & - & - \\
\hline S. mammalis & CE15054 & NOR Hordaland & 59.7067 & 6.0477 & NVLUM028-21 & MW535843 & MW544105 & MW534332 & MW542625 \\
\hline S. mammalis & CE15055 & NOR Hordaland & 59.7067 & 6.0477 & NOEAR066-18 & MW535861 & - & - & - \\
\hline S. mammalis & CE15056 & NOR Hordaland & 59.7067 & 6.0477 & NOEAR067-18 & MW535871 & - & - & - \\
\hline S. mammalis & CE15057 & NOR Hordaland & 59.7067 & 6.0477 & NVLUM029-21 & MW535865 & - & MW534335 & MW542626 \\
\hline S. mammalis & CE15058 & NOR Hordaland & 59.7067 & 6.0477 & NVLUM030-21 & MW535857 & - & MW534336 & MW542627 \\
\hline S. mammalis & CE15059 & NOR Hordaland & 59.7067 & 6.0477 & NVLUM031-21 & MW535845 & MW544104 & MW534330 & MW542628 \\
\hline \multirow[t]{2}{*}{ S. mammalis } & CE15060 & NOR Hordaland & 59.7067 & 6.0477 & NVLUM032-21 & MW535864 & MW544091 & MW534329 & MW542629 \\
\hline & & & & & & $\begin{array}{c}12 S \\
\text { MW538119 }\end{array}$ & $\begin{array}{c}18 \mathrm{~S} \\
\text { MW538114 }\end{array}$ & $\begin{array}{c}28 \mathrm{~S} \\
\text { MW538300 }\end{array}$ & \\
\hline \multirow[t]{2}{*}{ S. mammalis } & CE18431 & NED Gelderland & 51.793 & 5.298 & NVLUM033-21 & MW535856 & MW544096 & MW534328 & MW542630 \\
\hline & & & & & & $\begin{array}{c}12 S \\
\text { MW538120 }\end{array}$ & $\begin{array}{c}18 \mathrm{~S} \\
\text { MW538115 }\end{array}$ & $\begin{array}{c}28 \mathrm{~S} \\
\text { MW538301 }\end{array}$ & \\
\hline S. mammalis & CE21316 & NOR Rogaland & 59.0163 & 6.0436 & NVLUM034-21 & MW535869 & - & MW534337 & MW542631 \\
\hline
\end{tabular}

Operon (Ebersberg, Germany); 17 specimens were handled by the Canadian Centre for DNA Barcoding (CCDB) (Guelph, Canada), with COI data stored at the Barcode of Life Datasystems (BOLD). For four of these latter worms, DNA was also extracted at the University of Gothenburg, which enabled sequencing of some of the remaining markers (for details, see Table 1). For two specimens each of $H$. oculatus and S. mammalis the markers 12S, 18S and 28S (D1D2 region) were also amplified and sequenced (PCR-programs and primers listed in Table 2).

Sequences were assembled in Geneious Pro v. 7.1 (Biomatters Ltd.; http://www.geneious.com) and aligned separately for each species and gene using MAFFT v7.017 (Katoh et al. 2002), as implemented in Geneious Pro v. 7.1, using the auto-algorithm and default settings. In the $\mathrm{H} 3$ and ITS datasets, a few individuals showed clear signs of heterozygosity, i.e., distinct double peaks at certain positions in the sequencing chromatograms. Due to this, we separated H3 and ITS alleles using the PHASE algorithm (Stephens \& Donnelly 2003; Stephens et al. 2001) as implemented in DNAsp v. 5.10 (Librado $\&$ Rozas 2009). The phasing was run for 100 iterations after 100 initial burn-in iterations, with a thinning interval of 1 using default settings. For homozygous specimens only one of the two identical alleles were kept, for heterozygous specimen the two alleles are separated by the suffix _ 1 or 2 . All new sequences produced in this study are deposited in GenBank, and all $16 \mathrm{~S}$ and COI are also deposited on BOLD.

\section{Haplotype networks and genetic distances}

To visualize haplotype diversity, haplotype networks were constructed for all four genes of both species in PopART vl (Leigh \& Bryant 2015) using statistical parsimony (Clement et al. 2002; Templeton et al. 1992). For all markers, sections with missing data at the ends of the alignments, and for $16 \mathrm{~S}$ also sections with gaps, were masked and not included in the analysis. For COI we also constructed a second set of networks including additional publicly available sequences on BOLD. For Helodrilus four more sequences were added, and for Satchellius 20 more sequences were added (Appendix 2). However, although this set was based on a larger sample of specimens, the masked alignments obtained for the analyses were shorter than those used for the networks based on our own, more limited dataset; some of the BOLD sequences are only about $300 \mathrm{bp}$ long.

Uncorrected genetic p-distances were calculated for the COI datasets with only our data in MEGA X (Kumar et al. 2018), using pairwise deletion for missing data, the distances were analysed and summarised in a histogram, using $\mathrm{R}$ version 3.6.3 (with the packages ggplot2, dplyr, and readr). The alignments used for the networks, the distance files, and R-script are available at https:/github.com/SvanteMartinsson/Helodrilus_Satchellius.

\section{Phylogenetic analysis}

To estimate the systematic positions of the two species within Lumbricidae, sequences from Domínguez et al. (2015) were downloaded from Genbank, and combined with data from two of 
Table 2. List of PCR-primers and programs used in the study.

\begin{tabular}{|c|c|c|c|}
\hline Primer & Sequence 5'-3' & Reference & PCR-program \\
\hline \multicolumn{4}{|l|}{$\mathrm{COI}$} \\
\hline LCO1490 & GGTCAACAAATCATAAAGATATTGG & Folmer et al. (1994) & \multirow{3}{*}{$\begin{array}{l}95^{\circ} \mathrm{C} \text { for } 5 \text { min, } 35 \text { cycles each of } 95^{\circ} \mathrm{C} \text { for } 40 \mathrm{sec}, 45^{\circ} \mathrm{C} \text { for } 45 \mathrm{sec} \text { and } 72^{\circ} \mathrm{C} \\
\text { for } 60 \mathrm{sec} \text {, finally, } 72^{\circ} \mathrm{C} \text { for } 8 \mathrm{~min} .\end{array}$} \\
\hline HCO2198 & TAAACTTCAGGGTGACCAAAAAATCA & Folmer et al. (1994) & \\
\hline COI-E & TATACTTCTGGGTGTCCGAAGAATCA & Bely and Wray (2004) & \\
\hline \multicolumn{4}{|l|}{$16 \mathrm{~S}$} \\
\hline 16SAR-L & CGCCTGTTTATCAAAAACAT & Palumbi et al. (1991) & \multirow{2}{*}{$\begin{array}{l}95^{\circ} \mathrm{C} \text { for } 5 \mathrm{~min}, 35 \text { cycles each of } 95^{\circ} \mathrm{C} \text { for } 30 \mathrm{sec}, 50^{\circ} \mathrm{C} \text { for } 30 \mathrm{sec} \text { and } 72^{\circ} \mathrm{C} \\
\text { for } 60 \mathrm{sec} \text {, finally, } 72^{\circ} \mathrm{C} \text { for } 8 \mathrm{~min} \text {. }\end{array}$} \\
\hline 16SBRH & CCGGTCTGAACTCAGATCACGT & Palumbi et al. (1991) & \\
\hline \multicolumn{4}{|l|}{$\mathrm{H} 3$} \\
\hline $\mathrm{H} 3 \mathrm{~F}$ & ATGGCTCGTACCAAGCAGACVGC & Colgan et al. (1998) & \multirow{2}{*}{$\begin{array}{l}95^{\circ} \mathrm{C} \text { for } 5 \mathrm{~min}, 35 \text { cycles each of } 95^{\circ} \mathrm{C} \text { for } 30 \mathrm{sec}, 50^{\circ} \mathrm{C} \text { for } 30 \mathrm{sec} \text { and } 72^{\circ} \mathrm{C} \\
\text { for } 90 \mathrm{sec} \text {, finally, } 72^{\circ} \mathrm{C} \text { for } 8 \mathrm{~min} \text {. }\end{array}$} \\
\hline $\mathrm{H} 3 \mathrm{R}$ & ATATCCTTRGGCATRATRGTGAC & Colgan et al. (1998) & \\
\hline \multicolumn{4}{|l|}{ ITS2 } \\
\hline $606 \mathrm{~F}$ & GTCGATGAAGAGCGCAGCCA & Liu and Erséus (2017) & \multirow{2}{*}{$\begin{array}{l}95^{\circ} \mathrm{C} \text { for } 5 \mathrm{~min}, 35 \text { cycles each of } 95^{\circ} \mathrm{C} \text { for } 45 \mathrm{sec}, 55^{\circ} \mathrm{C} \text { for } 60 \mathrm{sec} \text { and } 72^{\circ} \mathrm{C} \\
\text { for } 90 \mathrm{sec} \text {, finally, } 72^{\circ} \mathrm{C} \text { for } 8 \mathrm{~min}\end{array}$} \\
\hline $1082 \mathrm{R}$ & TTAGTTTCTTTTCCTCCGCTT & Liu and Erséus (2017) & \\
\hline \multicolumn{4}{|l|}{$12 \mathrm{~S}$} \\
\hline 12SE1 & AAAACATGGATTAGATACCCRYCTAT & Jamieson et al. (2002) & \multirow{2}{*}{$\begin{array}{l}95^{\circ} \mathrm{C} \text { for } 5 \mathrm{~min}, 43 \text { cycles each of } 95^{\circ} \mathrm{C} \text { for } 40 \mathrm{sec}, 45^{\circ} \mathrm{C} \text { for } 45 \mathrm{sec} \text { and } 72^{\circ} \mathrm{C} \\
\text { for } 1 \mathrm{~min} \text {, finally } 72^{\circ} \mathrm{C} \text { for } 8 \mathrm{~min}\end{array}$} \\
\hline $12 \mathrm{SH}$ & ACCTACTTTGTTACGACTTATCT & Jamieson et al. (2002) & \\
\hline \multicolumn{4}{|l|}{$18 \mathrm{~S}$} \\
\hline TimA & AMCTGGTTGATCCTGCCAG & Norén and Jondelius (1999) & \multirow{4}{*}{$\begin{array}{l}95^{\circ} \mathrm{C} \text { for } 5 \mathrm{~min}, 30 \text { cycles each of } 95^{\circ} \mathrm{C} \text { for } 30 \mathrm{sec}, 60^{\circ} \mathrm{C} \text { for } 30 \mathrm{sec}, 72^{\circ} \mathrm{C} \text { for } \\
1 \mathrm{~min} \text { and } 30 \mathrm{sec} \text {, finally } 72^{\circ} \mathrm{C} \text { for } 8 \mathrm{~min} \text {. }\end{array}$} \\
\hline $1100 \mathrm{R}$ & GATCGTCTTCGAACCTCTG & Norén and Jondelius (1999) & \\
\hline $600 \mathrm{~F}$ & GGTGCCAGCMGCCGCGGT & Norén and Jondelius (1999) & \\
\hline TimB & TGATCCATCTGCAGGTTCACCT & Norén and Jondelius (1999) & \\
\hline \multicolumn{4}{|l|}{$28 \mathrm{~S}$} \\
\hline $28 \mathrm{SCl}$ & ACCCGCTGAATTTAAGCAT & Jamieson et al. (2002) & \multirow{2}{*}{$\begin{array}{l}95^{\circ} \mathrm{C} \text { for } 5 \mathrm{~min}, 35 \text { cycles each of } 95^{\circ} \mathrm{C} \text { for } 30 \mathrm{sec}, 50^{\circ} \mathrm{C} \text { for } 30 \mathrm{sec} \text { and } 72^{\circ} \mathrm{C} \\
\text { for } 1 \mathrm{~min} \text {, finally, } 72^{\circ} \mathrm{C} \text { for } 8 \mathrm{~min} \text {. }\end{array}$} \\
\hline 28SD2' & TCCGTGTTTCAAGACGG & Jamieson et al. (2002) & \\
\hline
\end{tabular}

our H. oculatus worms (CE11393 and 18777) and two S. mammalis (CE15060 and 18431). Six gene regions were used: 12S (including tRNA-Val), 16S (including tRNA-Leu, tRNA-Ala, and tRNA-Ser), $18 \mathrm{~S}, 28 \mathrm{~S}, \mathrm{COII}$, and $\mathrm{NADH}$, but the latter two were missing for our specimens, and for $12 \mathrm{~S}$ and $16 \mathrm{~S}$ we amplified a shorter fragment, not including any tRNAs. Each region was aligned using MAFFT v7.017 (Katoh et al. 2002), as implemented in Geneious Pro v. 7.1, using the auto-algorithm and default settings, and trimmed at the ends to reduce the amount of missing data, especially for $18 \mathrm{~S}$ and $28 \mathrm{~S}$, where the sequences from Domínguez et al. (2015) and our newly produced sequences where only partly overlapping. The alignments were then concatenated, and the dataset was trimmed to remove specimens from species with more than two specimens and/or specimens with too much missing data. The final dataset included 110 specimens and was 5,188 bp long. Trees were estimated with Maximum Likelihood (ML) using phyML 3.0 (Guindon et al. 2010), and Bayesian Inference (BI) using MrBayes 3.2.7 (Ronquist et al. 2012). For the ML analysis, Smart Model Selection (Lefort et al. 2017) with Bayesian Information criterion was used for automatic model selection; and Nearest Neighbour Interchange was used for tree improvement. Branch support was calculated with the SH-like (Shimodaira-Hasegawa test-like) approximative Likelihood Ratio Test (aLRT) (Anisimova \& Gascuel 2006). For the BI analysis the dataset was partitioned into genes, partitions were unlinked. Rate variation across sites was set to gamma distribution with a proportion of invariable sites; model jumping was implemented to integrate over substitution model space. The analyses were run for 50 million generations sampling every 10000 generations, the first $25 \%$ were discarded as burn-in, and a majority-rule consensus tree was constructed. The trees were drawn in FigTree 1.4.2 (Rambaut 2014) and further edited in Adobe Illustrator and Inkscape. Taxon names are updated in accordance with Szederjesi and Csuzdi (2016), Csuzdi et al. (2017), and Marchán et al. (2018). The alignments and output files from the analysis are available at https:/github.com/Svante-Martinsson/Helodrilus_Satchellius.

\section{RESULTS}

\section{Identification of specimens}

Sexually mature worms (Figs. 1B, D) were identified using Sims \& Gerard (1985), while identification of immature individuals was based on clustering of the COI barcodes. For some specimens of Helodrilus oculatus, we observed the characteristic lateral dark spots in some segments, large male pores (Figure 1C, mp), ridge-shaped tubercula pubertatis on XXIX-XXX (Figure 1C, tp), and closely paired chaetae that often have black tips (Figure 1C, ch). The segmental spots were visible also immediately after preservation in ethanol, but they appeared to fade with time in the fluid. The original author (Hoffmeister 1845: 39) claimed that the lateral spots (by him regarded as eye-spots, hence the name oculatus) and the black chaetae only occur in large and assumedly old worms.

For the sexually mature Satchellius mammalis, we noted, in particular, the conspicuous bulbous area surrounding each male pore in segment XV (Figure 1D, mp), small tubercula pubertatis on XXXIII-XXXIV (Figure 1D, tp), and widely paired chaetae (Figure 1D, ch). 


\section{Sequences}

For Helodrilus oculatus COI was successfully sequenced for all 39 specimens, and the alignment is $658 \mathrm{bp}$ long, of which $566 \mathrm{bp}$ were used to construct a haplotype network; 16S was sequenced for 19 specimens, and the alignment is $485 \mathrm{bp}$ long, of which $482 \mathrm{bp}$ were used to construct the haplotype network; ITS2 for 23 specimens, and after phasing with 38 sequences, $547 \mathrm{bp}$, of which 527 bp were used to construct the haplotype network; and $\mathrm{H} 3$ for 25 specimens, after phasing with 29 sequences, $328 \mathrm{bp}$, of which $286 \mathrm{bp}$ were used to construct the haplotype network. Sequences of $12 \mathrm{~S}, 18 \mathrm{~S}$ and $28 \mathrm{~S}$ were also obtained from specimens CE11393 and CE18777.

For Satchellius mammalis COI was successfully sequenced for all 14 specimens, and the alignment is $658 \mathrm{bp}$ long, of which $619 \mathrm{bp}$ were used to construct a haplotype network; $16 \mathrm{~S}$ was sequenced for eight specimens, and the alignment is $483 \mathrm{bp}$ long, of which $480 \mathrm{bp}$ were used to construct the haplotype network; ITS2 for 11 specimens, and after phasing with 12 sequences, $564 \mathrm{bp}$, of which $531 \mathrm{bp}$ were used to construct the haplotype network; and $\mathrm{H} 3$ for 11 specimens, after phasing with 12 sequences, $328 \mathrm{bp}$, of which $297 \mathrm{bp}$ were used to construct the haplotype network. Sequences of $12 \mathrm{~S}, 18 \mathrm{~S}$ and $28 \mathrm{~S}$ were also obtained from specimens CE15060 and 18431.

\section{New north-west European records}

Specimens of Helodrilus oculatus were found at one locality in southeastern Norway, the Vigeland Park in Oslo, and ten localities in Sweden; six sites all in close proximity to each other in Gothenburg (province Västergötland), and one in each of the provinces Uppland, Gotland, Blekinge, and (eastern) Skåne (Figure 2). We also include two specimens from a locality in eastern Denmark (Bornholm) and one from southern Germany (Bavaria). All localities represent wet habitats, and include riverbanks, ditches, ponds, and groundwater seepages.

Satchellius mammalis was found at four localities in southwestern Norway (two in Hordaland, and two in Rogaland) and three in Sweden (two in Gothenburg, and one in province Småland), we also obtained one specimen from the Netherlands (Gelderland) (Figure 2). The localities include composts and deciduous woodland.

The two species were found together at one locality in Gothenburg, a stream bank in a deciduous woodland.

\section{Haplotype networks and genetic distances}

For Helodrilus oculatus (Figure 3 A-D) five haplotypes were found in COI, divided in two well-separated groups (clusters), one with an eastern distribution, with specimens from the Swedish east coast (Uppland, Gotland, Blekinge and Skåne) and easternmost Denmark (Bornholm), and the other with a western distribution, i.e., the worms from Norway and western Sweden; the German individual is included in this latter group too. Four 16S haplotypes, five H3 haplotypes and four ITS2 haplotypes were found. In the latter three markers, no clear haplotype groups are observed; for each of H3 and ITS most sequences are the same haplotype, and the rare haplotypes are separated from it by only 1-2 substitutions.

For Satchellius mammalis (Figure 3 E-H) six COI haplotypes were found in three well separated groups, one with most of the Norwegian specimens and all individuals from Sweden, another with one specimen from Norway and one from the Netherlands, and the third with only a single specimen from Norway. Four 16S haplotypes, two H3 haplotypes, and two ITS2 haplotypes were found. In the latter three markers no clear groups are observed; for each of H3 and ITS most sequences are the same haplotype, and the rare haplotypes are separated from it by only 1-2 substitutions.

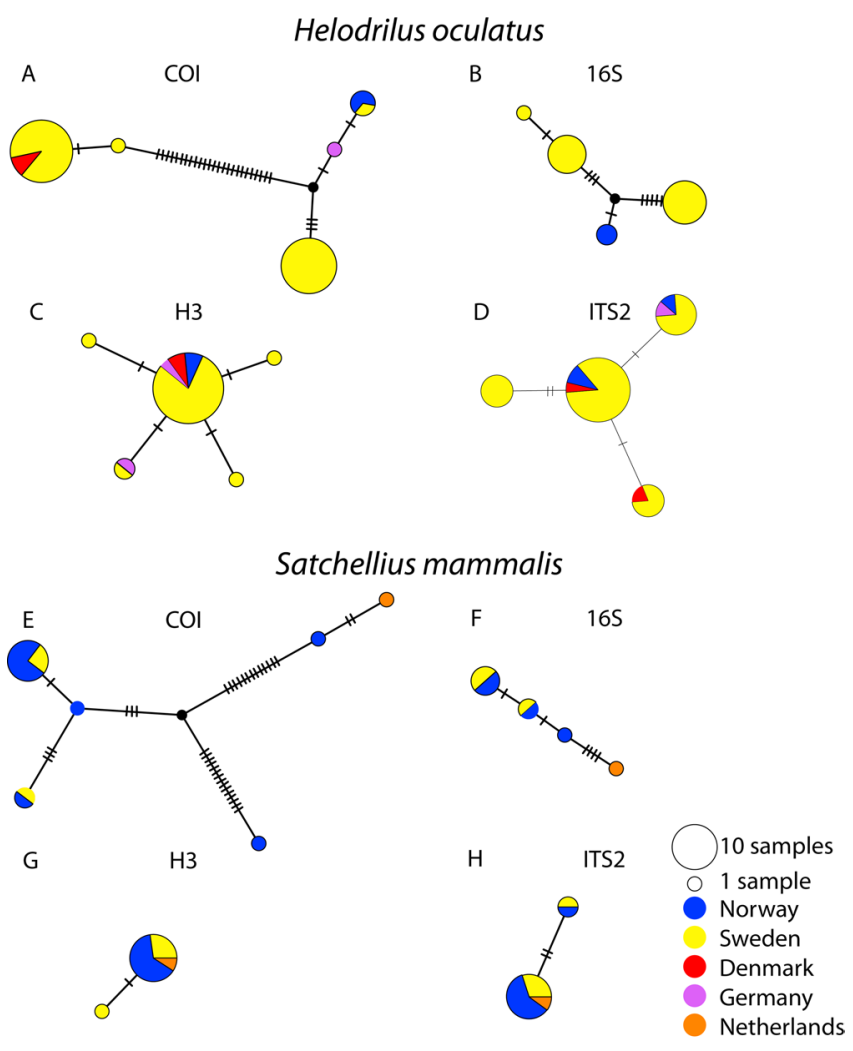

Figure 3. Statistical parsimony haplotype networks for Helodrilus oculatus (A-D) and Satchellius mammalis (E-H). A, E. COI networks, data from newly sequenced specimens only; B, F. 16S networks; C, G. H3 network; D, H. ITS2 networks. The size of the circles is relative to the number of sequences sharing that haplotype, the colours correspond to country of origin, and the hatch marks denote the number of substitutions between haplotypes.

The COI networks including publicly available data (Figure 4) are similar to the networks based on our data only. In the H. oculatus network, based on 285 bp, records from Geneva, Switzerland (Vivien et al. 2017; Vivien et al. 2015), Aarhus, Denmark (Møller et al. 2015; Lund et al. 2006), and Germany match our "western" group. In the $S$. mammalis network, based on $308 \mathrm{bp}$, the majority of our data is close to a record from Normandie, France, one of our records from Norway is close to records from Aarhus, Denmark (Møller et al. 2015), and one of our Norwegian records and the one from the Netherlands cluster together with records from Ireland (Klarica et al. 2012), and Aarhus, Denmark (Møller et al. 2015).

The uncorrected COI p-distances for Helodrilus oculatus vary between 0.000 and 0.055 , with a gap between 0.008 and 0.044 , and for Satchellius mammalis the distances vary between 0.000 and 0.049 , with a gap between 0.006 and 0.027 (Figure 5).

\section{Phylogenetic analysis}

The tree resulting from the ML analysis (Figure 6) is largely well supported and congruent with the trees in Domínguez et al. (2015). However, we do not recover Lumbricidae as monophyletic; Criodrilus lacuum Hoffmeister, 1845 (Criodrilidae) is found as sister to Diporodrilus pilosus Bouché, 1970, but without support. Helodrilus oculatus is found in a clade also containing $H$. patriarchalis (Rosa, 1893) and H. cernosvitovianus (Zicsi, 1967), whereas the last member of Helodrilus included in the tree, H. cortezi Qui \& Bouché, 2000, is well separated from the rest and being the sister to Allolobophora chaetophora Bouché, 1972, despite being listed as a junior synonym to H. oculatus (Szederjesi et al. 2014). Satchellius is not monophyletic 
A

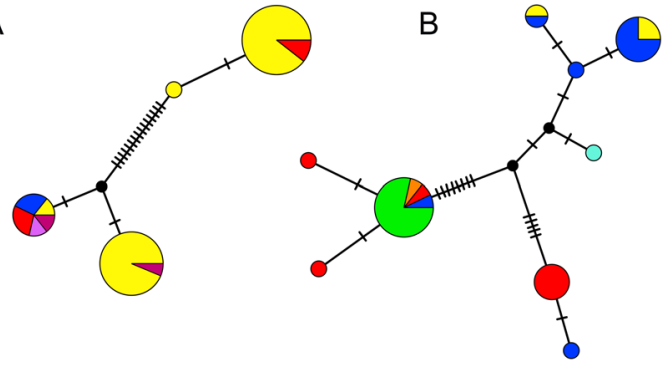

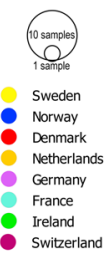

Figure 4. Statistical parsimony haplotype networks for Helodrilus oculatus (A) and Satchellius mammalis (B). The networks are constructed with a combination of our data and publically available data from BOLD. The size of the circles is relative to the number of sequences sharing that haplotype, the colours correspond with country of origin, and the hatch marks correspond to the number of substitutions between haplotypes.

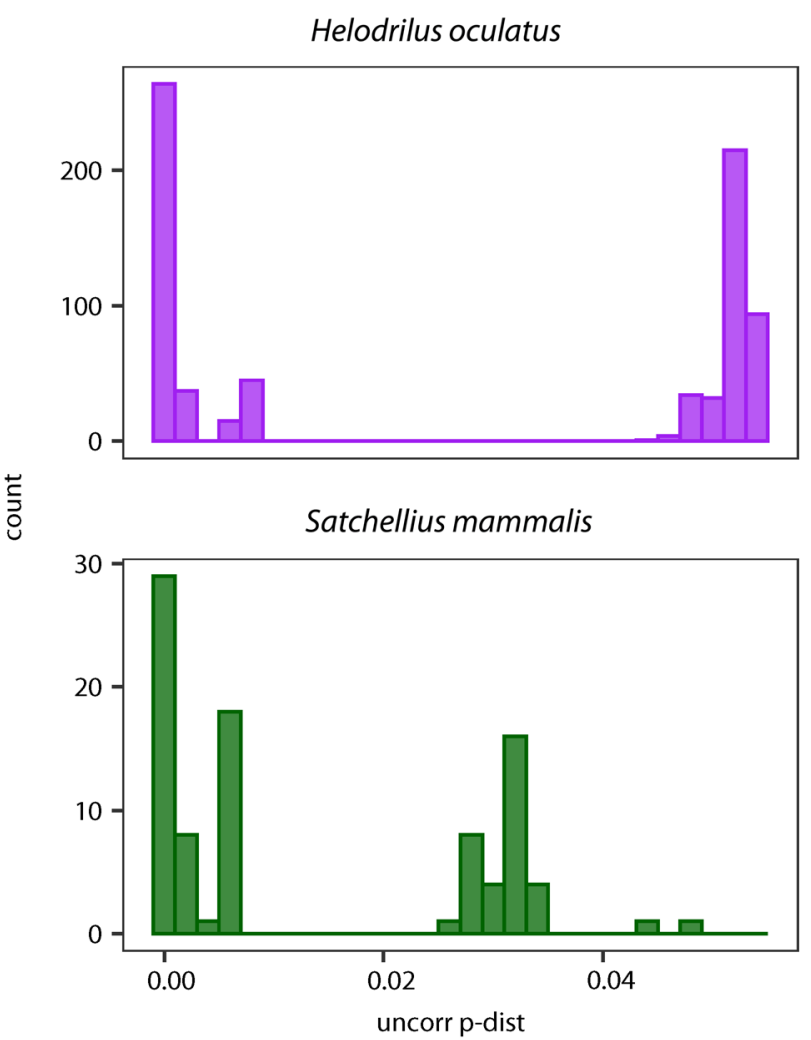

Figure 5. Histograms of uncorrected pairwise genetic distances in COI for our specimens of Helodrilus oculatus and Satchellius mammalis.

either, S. mammalis is found as sister to a Healyella sp., in a clade also including Eiseniella Michaelsen, 1900, Eiseniona Omodeo, 1956, and part of Dendrobaena Eisen, 1874. The other species of Satchellius, S. madeirensis is instead found in a clade including Proctodrilus antipai (Michaelsen, 1891) and an unidentified Lumbricidae; this clade is the sister to the Helodrilus clade.

The Bayesian analysis had problem with convergence, and the resulting tree (Appendix 3) is generally less resolved than the ML tree. Lumbricidae is not recovered as monophyletic, instead, there is a trichotomy consisting of Criodrilus lacuum, Diporodrilus pilosus, and remaining Lumbricidae. Neither Helodrilus nor Satchellius are recovered as monophyletic. Helodrilus oculatus is recovered as sister to $H$. patriarchalis, but without support, these two species are found in a large polytomy, where also $H$. cernosvitovianus is found. The last species of Helodrilus, H. cortezi is found together with Allolobophora cheatophora as sister to the large polytomy where the other Helodrilus

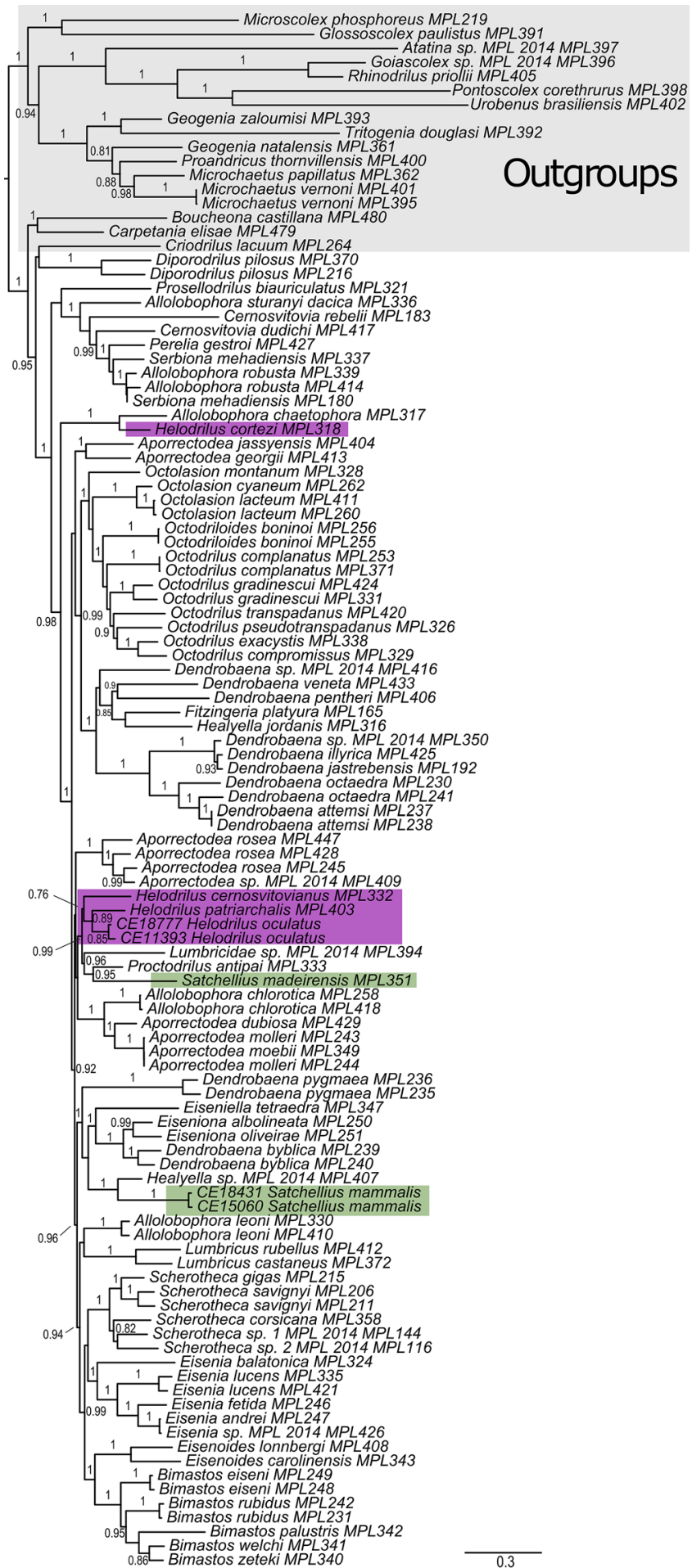

Figure 6. Lumbricidae phylogeny based on data from Domínguez et al. (2015) and newly produced sequences from Helodrilus oculatus and Satchellius mammalis. The phylogeny is based on a concatenated data matrix consisting of 110 specimens and it is 5,188 bp long. The phylogeny is estimated using ML in phyML. Numbers at branches are SH-like aLRT support values, only values $>0.75$ are shown. Scale shows expected number of changes per site.

species are found. Satchellius mammalis is recovered together with a Dendrobaena sp. but without support, these two are found in the large polytomy mentioned above; $S$. madeirensis is found in this polytomy too. 


\section{DISCUSSION}

This study confirms that Helodrilus oculatus and Satchellius mammalis are two well established species in the southern Scandinavia. However, on the basis of their relative scarcity in a very large collection of Lumbricidae assembled and DNA-barcoded in Sweden and Norway during the last 10-15 years (Erséus and co-workers, largely unpublished; but see also James et al. 2010; Martinsson \& Erséus 2017; Martinsson \& Erséus 2018; Martinsson et al. 2017), we see no evidence of them spreading rapidly in the Nordic countries. For $S$. mammalis, this is in line with the attribute given to this taxon of being "uncommon" on the British Isles (Sherlock 2018), and it is noteworthy that the currently known Norwegian distribution of this species (Figure 2) is restricted to the southwestern coastline of the country. In Sweden, the species is truly rare, with only a total of three individuals being found in two southern provinces (Västergötland and Småland). Helodrilus oculatus is largely an aquatic worm, in Sweden and Norway associated with muddy substrates near some streams and small rivers, which is in accordance with what is known about the habitat preferences of the species (Sherlock 2018; Sims \& Gerard 1985; Szederjesi et al. 2014). On the British Isles H. oculatus is "very rare" (Sherlock 2018), whereas it seems quite well spread in southern Scandinavia (Figure 2), but so far it is only known from one locality in Norway (a park in Oslo). Helodrilus oculatus also has a wider European distribution compared with that of $S$. mammalis, which appears restricted to Western Europe (Sherlock 2018; Sims \& Gerard 1985; Szederjesi et al. 2014; Szederjesi \& Csuzdi 2016).

Despite the existence of clear haplotype clusters in COI for both species, nothing else suggests that there are cryptic species in our material. The lack of structure in H3 and ITS2, with most sequences being identical, in particular, support that we only have one species of Helodrilus and Satchellius respectively in our dataset. Further, the distances between the COI clusters are smaller than what is commonly seen between different, but closely related lumbricid species, where distances as a rule are well above 10\% (e.g., Martinsson \& Erséus 2017; Pérez-Losada et al. 2012), whereas in our dataset of $H$. oculatus and S. mammalis the maximal intra-specific distances are about $5 \%$.

The high genetic variation, in COI, in both species does not seem to support single introductions, but rather that each species has arrived to the Scandinavian Peninsula from more than one source population, and thus at more than one occasion. In $H$. oculatus the two COI haplogroups match the distribution, with one eastern group from Blekinge, Gotland, Uppland, southeastern Skåne and Bornholm, and one western group from Gothenburg and Oslo that also is found in Bavaria, southern Germany. This could indicate two distinct colonisation routes into Scandinavia, from two separate populations. In S. mammalis no such pattern can be seen, but with its more limited general (West European) distribution, and fewer specimens included in the present study, this is not surprising. However, in all three groups, there are matching records from outside the Scandinavian Peninsula, but without any apparent pattern. In a phylogeographical study of the earthworms of the French Mediterranean Hyères archipelago Marchán et al. (2020) discovered two different patterns, one of local in situ divergence during the Plio-Pleistocene ( $\sim 5$ mya to $12 \mathrm{kya}$ ), with clades restricted to the archipelago, and one characterised by the lack of geographical structure, and with the clades represented in the archipelago having a wide distribution. The latter pattern is consistent with human-mediated introduction. Lack of geographical structure is commonly seen in the Scandinavian earthworm fauna (e.g., Martinsson \& Erséus 2017), and H. oculatus is one of the few species with a clear geographical structure so far observed. This is, however, not surprising as Scandinavia until recently was ice-covered, and earthworms and other fauna are recent colonisers.

Both phylogenetic analyses showed that, as currently defined, neither Helodrilus nor Satchellius are monophyletic. Unfortunately, the Bayesian analysis had problems with convergence, which probably, at least partly explains the poor resolution in the resulting tree. Both trees recover H. oculatus, the type species of Helodrilus, as sister to $H$. patriarchalis, and in the ML tree $H$. cernosvitovianus is sister to them, forming a clade that can be considered Helodrilus s.str. In both trees $H$. cortezi is instead found together with Allolobophora cheatophora, despite being listed as a synonym to $H$. oculatus in Szederjesi et al. (2014). In the ML tree Satchellius mammalis is found as the sister to a Healyella $s p$. and together found within a clade consisting of some Dendrobaena species, and Eiseniona and Eiseniella, which is interesting as both Satchellius and some species of Healyella have been regarded as members of Dendrobaena (Gates 1975; Omodeo \& Rota 1989), and both have calciferous glands with diverticula in X (Csuzdi et al. 2017; Gates 1975). On the other hand, in the BI tree, $S$. mammalis is found together with Dendrobaena $s p$. but without support. The second included species, S. madeirensis is not recovered close to $S$. mammalis. In the ML tree it is found in the sister clade to Helodrilus s.str., whereas in the BI tree it is found in a large polytomy. The taxonomy of this species is complicated. The sequences used here are from a specimen identified as $S$. gatesi by Domínguez et al. (2015), a species that was synonymised with Allobophora madeirensis Michaelsen, 1891 by Szederjesi and Csuzdi (2016), while still regarding it as a member of Satchellius. In the latter paper a new species, Zophoscolex zicsianus Szederjesi \& Csuzdi, 2016, was described based on material that was considered conspecific to A. madeirensis by Zicsi (1969), but Z. zicsianus is to our knowledge so far only found on the island of Madeira. The specimen used by Domínguez et al. (2015) is from northwestern Spain and it seems likely that it is conspecific with $S$. madeirensis.

Our new records of $H$. oculatus and S. mammalis are all from within the last 15 years. As Julin (1949) and Stöp-Bowitz (1969) gave no evidence of their existence on the Scandinavian Peninsula ca. 55-75 years earlier, it seems likely that the species have been, and still are, in a process of range extension towards the north. Our data are too limited to enable conclusions about the speed of the spread or whether these new taxa have any negative effect on other earthworms or the Scandinavian ecosystems as such. However, the scarce and patchy distribution of our records, as well as other findings in Europe, suggest that $H$. oculatus and $S$. mammalis probably should not be regarded as invasive earthworms.

\section{ACKNOWLEDGEMENTS}

We are grateful to Ainara Achurra, Anna Ansebo, Seana Davidson, Gerhard Falkner, Yingkui Liu, Sam James, Ted von Proschwitz, Emilia Rota, Joachim Sturve, Christiane Todt, Ton van Haaren, and Bronwyn Williams for providing specimens and/or assisting in field work; and to Anna Ansebo, Angelica Ardehed, Emelie Lindström, and Peter Samsson for lab assistance. The study was funded by the Swedish Taxonomy Initiative, Swedish Species Information Centre (SLU ArtDatabanken); the Norwegian Taxonomy Initiative, Norwegian Biodiversity Information Centre (Artsdatabanken); the Swedish EPA's Environmental Research Fund in collaboration with the Swedish Agency for Marine and Water Management; the Adlerbert Research Foundation; and the Royal Society of Arts and Sciences in Gothenburg (KVVS). 


\section{REFERENCES}

Anisimova M and Gascuel O. 2006. Approximate likelihood-ratio test for branches: A fast, accurate, and powerful alternative, Systematic Biology. 55(4): 539-552. doi: 10.1080/10635150600755453.

Beddard FE. 1888. On certain points in the structure of Urochaeta, E. P., and Dichogaster, nov. gen., with further remarks on the nephridia of earthworms. Quarterly Journal of microscopical Science (n.s) 29: 235-282.

Bely AE and Wray GA. 2004. Molecular phylogeny of naidid worms (Annelida: Clitellata) based on cytochrome oxidase I. Molecular Phylogenetics and Evolution 30(1): 50-63. doi: 10.1016/s10557903(03)00180-5.

Blakemore RJ. 2007. Scandinavian earthworms - a checklist of species, Accessed 2020-11-17. http://www.annelida.net/earthworm/ Scandinavian.pdf.

Bouché MB. 1970. Remarques sur quelques Lumbricina de France et consequences de la decouverte des noveaux taxons Vignysinae (Subfam. nov) et Diporodrilidae (Fam. nov.). Pedobiologia 10: 246-256.

Clement M, Snell Q, Walke P, Posada D and Crandall, K. 2002. TCS: estimating gene genealogies. Proceedings of the $16^{\text {th }}$ International Parallel \& Distributed Processing Symposium 2: 184. doi: 10.1109/ IPDPS.2002.1016585.

Colgan DJ, McLauchlan A, Wilson GDF, Livingston SP, Edgecombe GD, Macaranas J, Cassis G and Gray MR. 1998. Histone H3 and U2 snRNA DNA sequences and arthropod molecular evolution. Australian Journal of Zoology 46(5): 419-437. doi: 10.1071/Zo98048.

Csuzdi C, Chang CH, Pavlícek T, Szederjesi T, Esopi D and Szlávecz K. 2017. Molecular phylogeny and systematics of native North American lumbricid earthworms (Clitellata: Megadrili). PLoS ONE 12(8): e0181504. doi: 10.1371/journal.pone.0181504.

Domínguez J, Aira M, Breinholt JW, Stojanovic M, James SW and PérezLosada M. 2015. Underground evolution: new roots for the old tree of lumbricid earthworms. Molecular Phylogenetics and Evolution 83: 7-19. doi: 10.1016/j.ympev.2014.10.024.

Eisen G. 1874. Om Skandinaviens lumbricider. Öfversigt af Kongliga Vetenskaps-Akademiens Förhandlingar 30(8): 43-56.

Erséus C, Omodeo P and Rota E. 1994. First records of the allochtonous species Dichogaster saliens and D. bolaui (Oligochaeta: Octochaetidae) from Sweden. Megadrilogica 6(2): 17-20.

Folmer O, Black M, Hoeh W, Lutz R and Vrijenhoek R. 1994. DNA primers for amplification of mitochondrial cytochrome $\mathrm{c}$ oxidase subunit I from diverse metazoan invertebrates. Molecular Marine Biology and Biotechnology 3(5): 294-299.

Gates GE. 1972. Contributions to North American earthworms (Annelida) No. 5. On variation in another anthropochorous species of the oriental earthworm genus Pheretima Kinberg 1866 (Megascolecidae). Bulletin of Tall Timbers Research Station 13: 18-44.

Gates GE. 1975. Contributions to a revision of the earthworm family Lumbricidae XII. Enterion mammale Savigny, 1826 and its position in the family. Megadrilogica 2(1): 1-5.

Guindon S, Dufayard JF, Lefort V, Anisimova M, Hordijk W and Gascuel O. 2010. New algorithms and methods to estimate maximumlikelihood phylogenies: assessing the performance of PhyML 3.0. Systematic Biology 59(3): 307-321. doi: 10.1093/sysbio/syq010.

Hoffmeister W. 1845. Die bis jetzt bekannten Arten aus der Familie der Regenwürmer. Als Grundlage zu einer Monographie dieser Familie. Friedrich Vieweg \& Sohn, Braunschweig.

James SW, Porco D, Decaens T, Richard B, Rougerie R and Erséus C. 2010. DNA barcoding reveals cryptic diversity in Lumbricus terrestris L., 1758 (Clitellata): resurrection of L. herculeus (Savigny, 1826). PLoS ONE 5(12): e15629. doi: 10.1371/journal.pone.0015629.

Jamieson BGM, Tillier S, Tillier A, Justine J-L, Ling E, James S, McDonald K and Hugall AF. 2002. Phylogeny of the Megascolecidae and Crassiclitellata (Annelida, Oligochaeta): combined versus partitioned analysis using nuclear (28S) and mitochondrial (12S, 16S)
rDNA. Zoosystema 24 (4): 707-734.

Julin E. 1949. De svenska daggmaskarterna. Arkiv för Zoologi 42: 1-58.

Katoh K, Misawa K, Kuma K and Miyata T. 2002. MAFFT: a novel method for rapid multiple sequence alignment based on fast Fourier trasform. Nucleic Acids Research 30(14): 3059-3066. doi: 10.1093/ nar/gkf436.

Kinberg JGH. 1886. Annulata nova [Continuatio. Fam. Lumbricina (Sav.). Öfversigt af Kongl. Vetenskaps-Akademiens Förhandlingar 23(4): 97-103.

Klarica J, Kloss-Brandstätter A, Traugott M and Juen A. 2012. Comparing four mitochondrial genes in earthworms - Implications for identification, phylogenetics, and discovery of cryptic species. Soil Biology and Biochemistry 45: 23-30. doi: 10.1016/j.soilbio.2011.09.018.

Kumar S, Stecher G, Li M, Knyaz C and Tamura K. 2018. MEGA $\mathrm{X}$ : Molecular Evolutionary Genetics Analysis across computing platforms.Molecular Biology and Evolution 35(6): 1547-1549. doi: 10.1093/molbev/msy096.

Lefort V, Longueville J-E and Gascuel O. 2017. SMS: Smart Model Selection in PhyML. Molecular Biology and Evolution 34(9): 24222424. doi: 10.1093/molbev/msx149.

Leigh JW and Bryant D. 2015. POPART: full-feature software for haplotype network construction. Methods in Ecology and Evolution 6(9): 1110-1116. doi: 10.1111/2041-210X.12410.

Librado P and Rozas J. 2009. DnaSP v5: a software for comprehensive analysis of DNA polymorphism data. Bioinformatics 25(11): 14511452. doi: 10.1093/bioinformatics/btp187.

Lund MB, Fritz M, Holmstrup M and Schramm A. 2006. Co-speciation of earthworms and their nephridial symbionts, Acidovorax spp. In: The Hidden Powers - Microbial Communities in Action. Proceedings of the $11^{\text {th }}$ International Symposium on Microbial Ecology (ISME-11), International Society for Microbial Ecology, Vienna, Austria. 182pp.

Marchán DF, Fernández R, de Sosa I, Sánchez N, Cosín DJD and Novo M. 2018. Integrative systematic revision of a Mediterranean earthworm family: Hormogastridae (Annelida, Oligochaeta). Invertebrate Systematics 32(3): 652-671. doi: 10.1071/is17048.

Marchán DF, Hedde M, Lapied E, Maggia M-E, Novo M, Domínguez J and Decaëns T. 2020. Contrasting phylogeographic patterns of earthworms (Crassiclitellata, Lumbricidae) on near-shore mediterranean islands. European Journal of Soil Biology 101: 103242. doi: 10.1016/j. ejsobi.2020.103242.

Martinsson S and Erséus C. 2017. Cryptic speciation and limited hybridization within Lumbricus earthworms (Clitellata: Lumbricidae). Molecular Phylogenetics and Evolution 106: 18-27. doi:10.1016/j. ympev.2016.09.011.

Martinsson S and Erséus C. 2018. Hybridisation and species delimitation of Scandinavian Eisenia spp. (Clitellata: Lumbricidae). European Journal of Soil Biology 88: 41-47. doi: 10.1016/j.ejsobi.2018.06.003.

Martinsson S, Rhodén C and Erséus C. 2017. Barcoding gap, but no support for cryptic speciation in the earthworm Aporrectodea longa (Clitellata: Lumbricidae). Mitochondrial DNA 28(2): 147-155. doi: 10.3109/19401736.2015.1115487.

Michaelsen W. 1891a. Oligochaeten des Naturhistorischen Museums in Hamburg. Part iv. Jahrbuch der Hamburgischen Wissenschaftlichen Anstalten 8: 299-340.

Michaelsen W. 1891b. Terricolen der Berliner Zoologischen Sammlung. I. Afrika. Archiv für Naturgeschichte, Berlin 57: 205-228.

Michaelsen W. 1900. Oligochaeta. Friedländer \& Sohn, Berlin.

Møller P, Lund MB and Schramm A. 2015. Evolution of the tripartite symbiosis between earthworms, Verminephrobacter and Flexibacterlike bacteria. Frontiers in Microbiology 6: 529. doi: 10.3389/ fmicb.2015.00529.

Norén M and Jondelius U. 1999. Phylogeny of the Prolecithophora (Platyhelminthes) inferred from 18S rDNA sequences. Cladistics,15(2): 103-112. doi: 10.1111/j.1096-0031.1999.tb00252.x.

Omodeo P. 1956. Contributo alla revisione dei Lumbricidae. Archivio zoologico Italiano 41: 129-212. 
Omodeo P and Rota E. 1989. Earthworms of Turkey. Bolletino di Zoologia 56(2): 167-198. doi: 10.1080/11250008909355639.

Palumbi SR, Martin A, Romano S, Mc-Millan WO, Stice L and Grabawski G. 1991. The simple fool's guide to PCR, version 2.0. Privately published, compiled by S. Palumbi., University of Hawaii, Honolulu.

Pérez-Losada M, Bloch R, Breinholt JW, Pfenninger M and Domínguez J. 2012. Taxonomic assessment of Lumbricidae (Oligochaeta) earthworm genera using DNA barcodes. European Journal of Soil Biology 48: 41-47. doi: 10.1016/j.ejsobi.2011.10.003.

Qiu J-P and Bouché MB. 2000a. Une nouvelle évaluation du genere Helodrilus (sensu Zicsi, 1985) (Oligochaeta: Lumbricidae). Documents Pedozoologiques \& Intégrologiques 4: 8-16.

Qiu JP and Bouché MB. 2000b. Contribution à la taxonimie des Dendrobaenini trib. Nov. (Oligochaeta: Lumbricidae): Iberoscolex gen. nov. et nouveaux taxons de Dendrobaena Eisen, 1874 et Satchellius Gates, 1975. Documents Pedozoologiques et Integrologiques 4(14): 153-163.

Rambaut A. 2014. FigTree v1.4.2. http://tree.bio.ed.ac.uk/software/figtree/ Ronquist F, Teslenko M, van der Mark P, Ayres DL, Darling A, Hohna S, Larget B, Liu L, Suchard MA and Huelsenbeck JP. 2012. MrBayes 3.2: efficient Bayesian phylogenetic inference and model choice across a large model space. Systematic Biology 61(3): 539-542. doi: 10.1093/ sysbio/sys029.

Rosa D. 1893. Viaggio del Dr. E. Festa in Palestina, nel Libano e regioni vicine.-II. Lumbricidi. Bollettino dei Musei di Zoologia ed Anatomia comparata della R. Università di Torino 8(160): 1-14.

Savigny JC. 1826. Analyses de travaux de l'Académie Royale des Sciences pendant l'année 1821, partie physique. Zoologie. Mémoires de l'Académie des sciences de l'Institut de France (Histoire) 5: 176-184.

Sherlock E. 2018. Key to the earthworms of the UK and Ireland. FSC, Telford.

Sims RW and Gerard BM. 1985. Earthworms: Keys and notes for the identification and study of the species. Brill, London.

Stephens M and Donnelly P. 2003. A comparison of bayesian methods for haplotype reconstruction from population genotype data. American Journal of Human Genetics 73(5): 1162-1169. doi: 10.1086/379378.

Stephens M, Smith NJ and Donnelly P. 2001. A new statistical method for haplotype reconstruction from population data. American Journal of Human Genetics 68(4): 978-989. doi: 10.1086/319501.

Stöp-Bowitz C. 1969. A contribution to our knowledge of the systematics and zoogeography of Norwegian earthworms (Annelida Oligochaeta: Lumbricidae). Nytt Magasin for Zoologi 17: 169-280.

Szederjesi T, Angyal D, Balázs G and Dányi L. 2014. Remarks on the earthworm genus Helodrilus Hoffmeister, 1845 with new epigean and subterranean records (Oligochaeta, Lumbricidae). Opuscula Zoologica 45(2): 181-188.

Szederjesi T and Csuzdi C. 2016. Review of the species allocated to the genus Satchellius (Oligochaeta: Lumbricidae) with description of a new species. Biologia 71(2): 169-175. doi: 10.1515/biolog-2016-0023.

Templeton AR, Crandall KA and Sing CF. 1992. A cladistic analysis of phenotypic associations with haplotypes inferred from restriction endonuclease mapping and DNA sequence data. III. Cladogram estimation. Genetics 132(2): 619-633.

Vivien R, Holzmann M, Werner I, Pawlowski J, Lafont M and Ferrari BJD. 2017. Cytochrome c oxidase barcodes for aquatic oligochaete identification: development of a Swiss reference database. PeerJ 5: e4122. doi: $10.7717 /$ peerj.4122.

Vivien R, Wyler S, Lafont M and Pawlowski J. 2015. Molecular barcoding of aquatic oligochaetes: implications for biomonitoring. PLoS ONE 10(4): e0125485. doi: 10.1371/journal.pone.0125485.

Zicsi A. 1967. Beiträge zur Kenntnis der ungarischen Lumbricidenfauna, IV. Opuscula Zoologica 6: 187-190.

Zicsi A. 1969. Regenwürmer (Lumbricidae) aus Madeira und von den Kanarischen Inseln. Acta Zoologica Hungarica 15: 243-246.
Editorial responsibility: Torkild Bakken.

This article is open-access and distributed under the terms of the Creative Commons Attribution 4.0 International license. This permits all noncommercial use, distribution, and reproduction in any medium, provided the original work is properly cited.

(http://creativecommons.org/licenses/by/4.0/). 


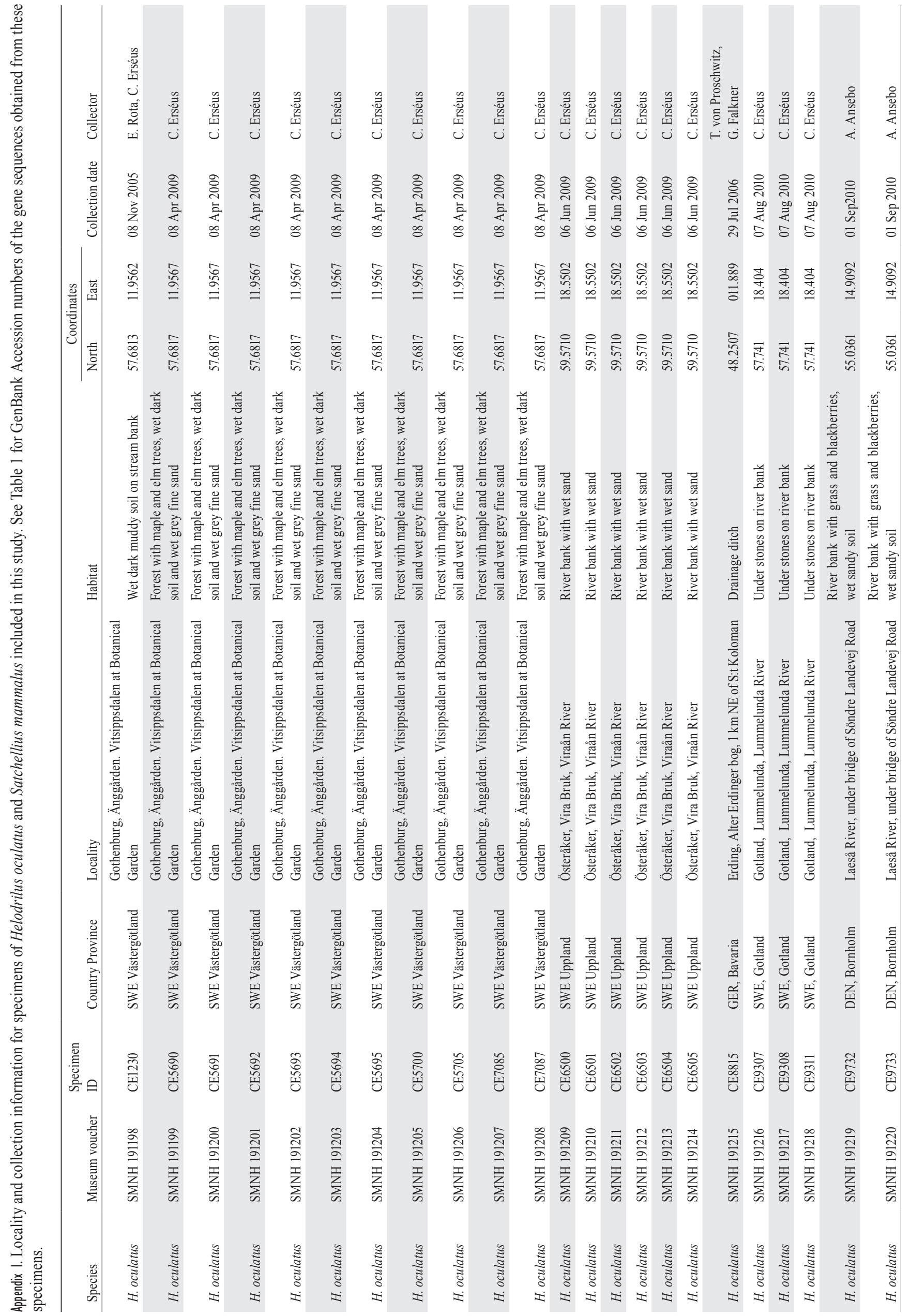




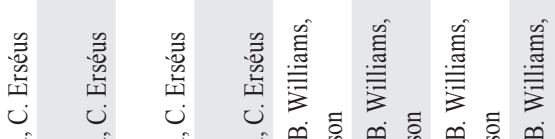

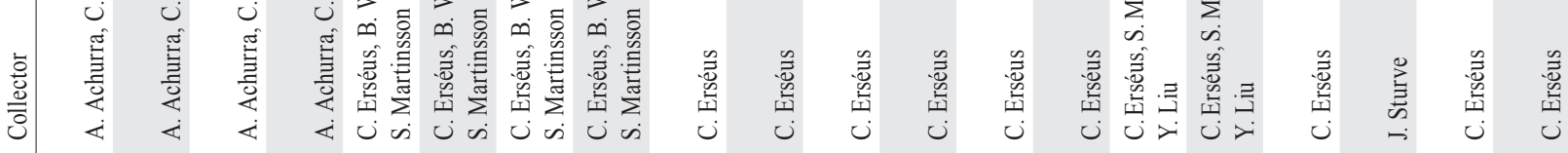

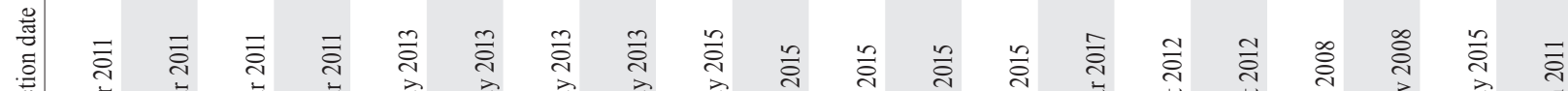

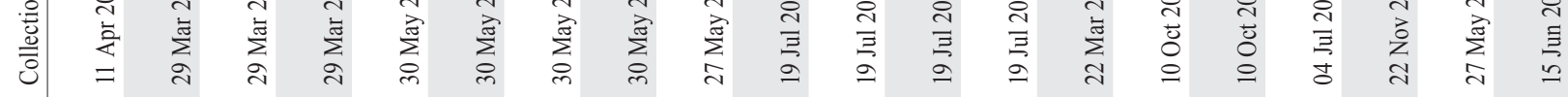

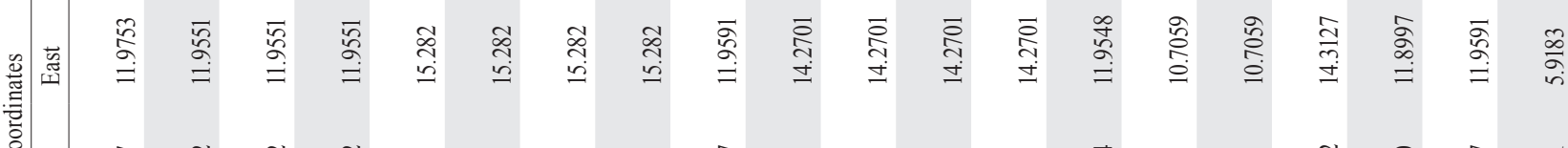

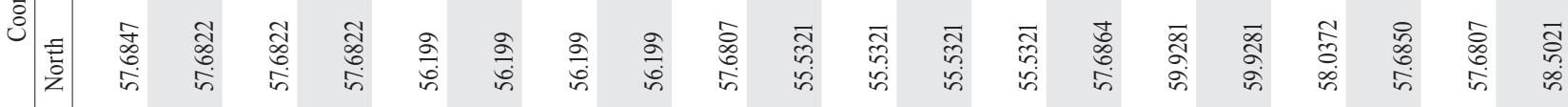

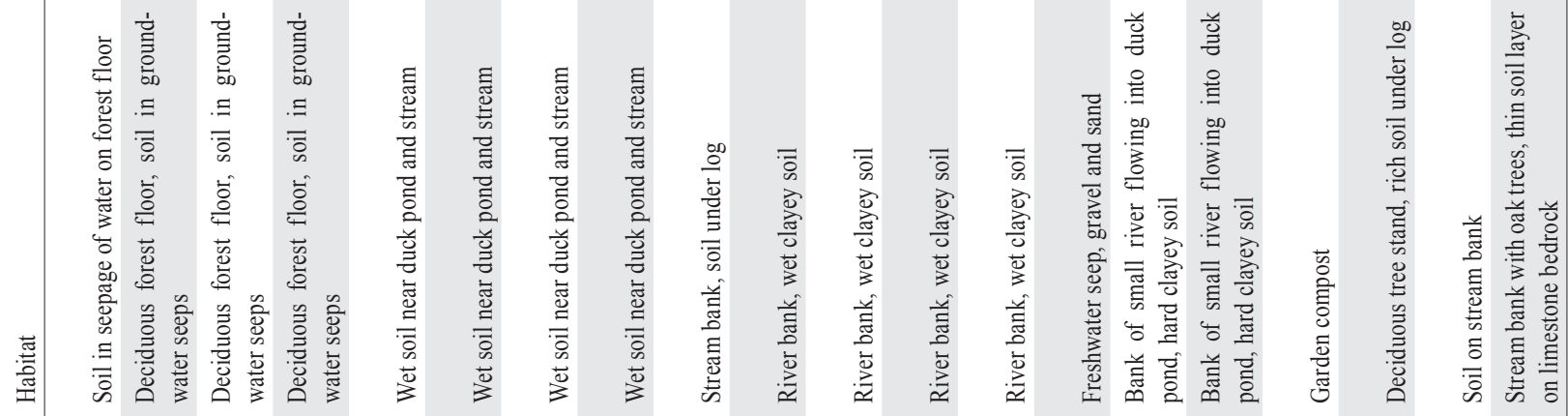

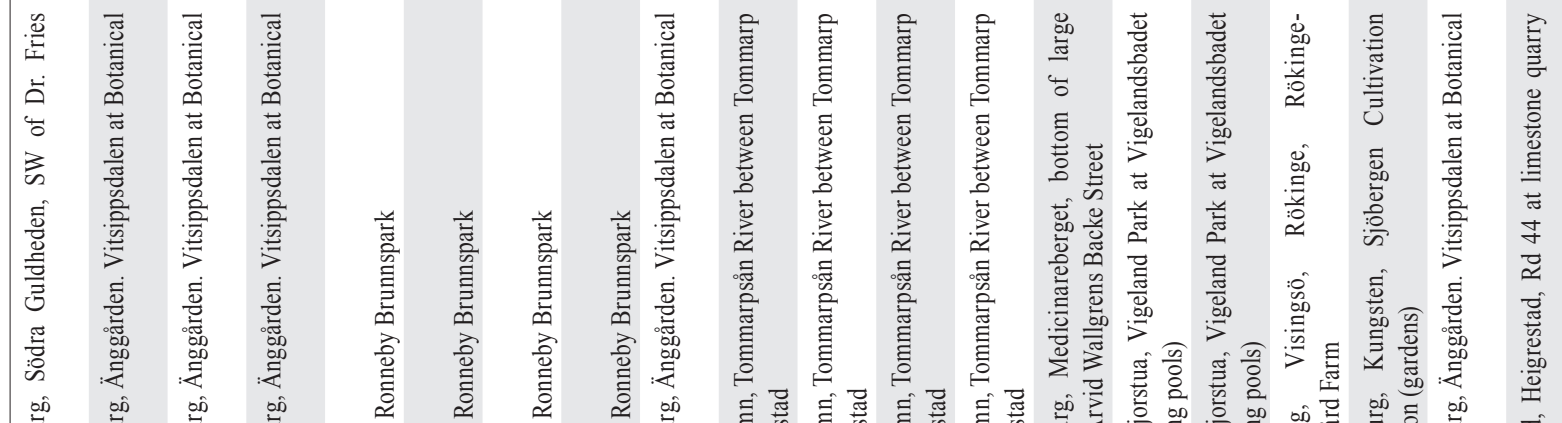

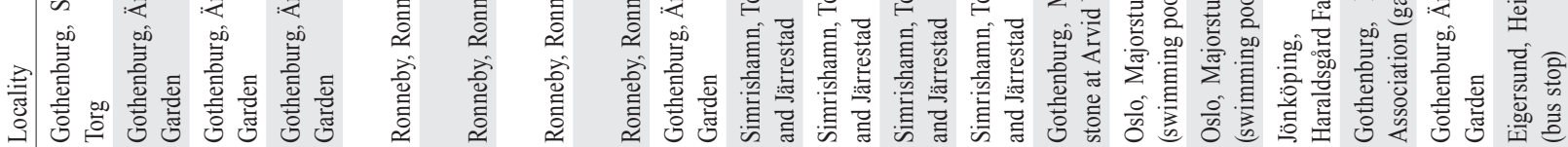

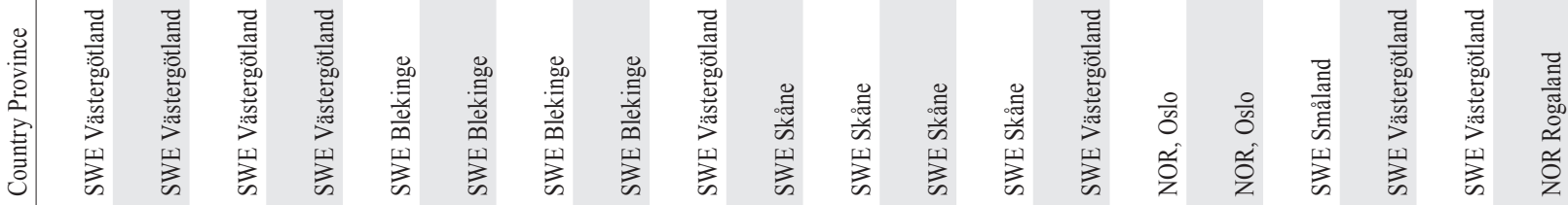

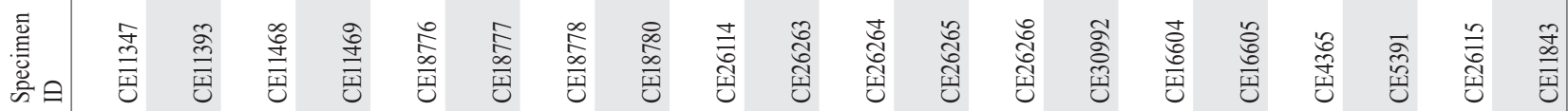

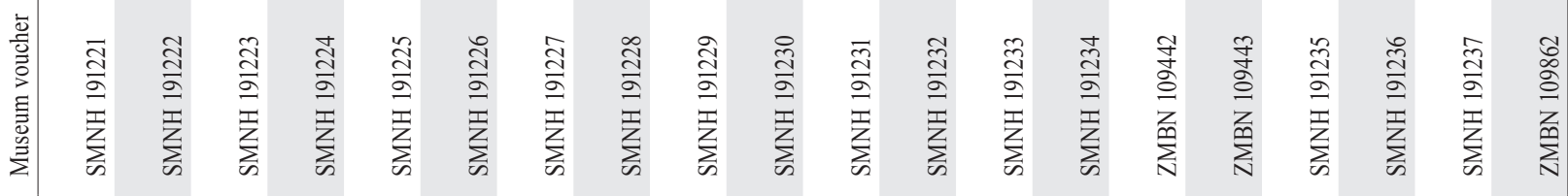

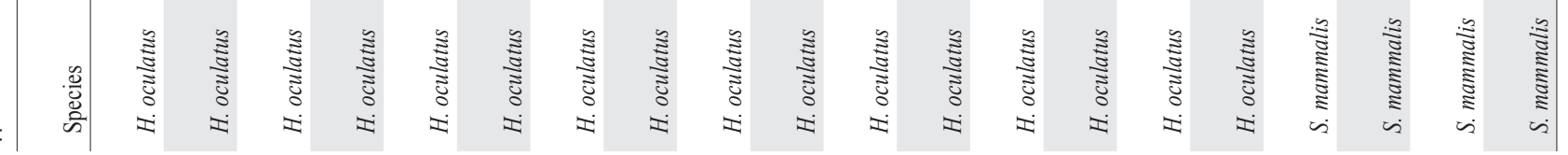




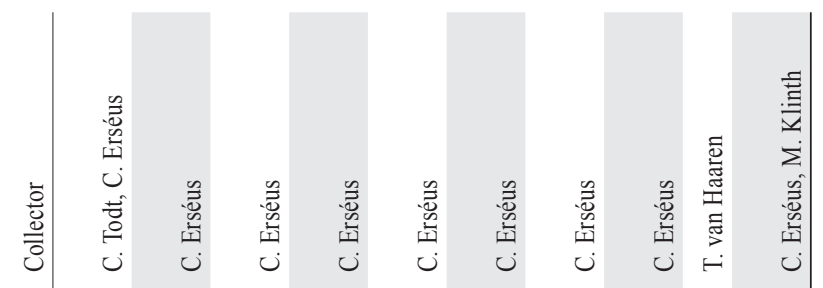

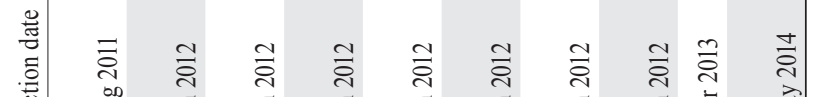

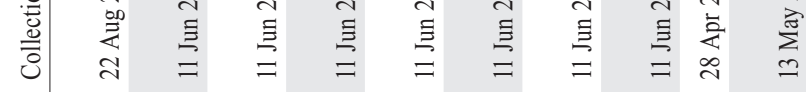

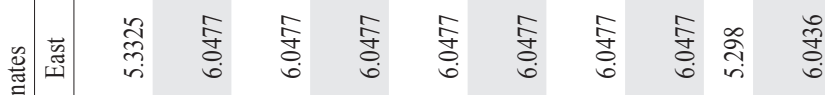
ن:

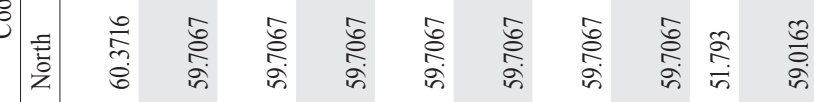

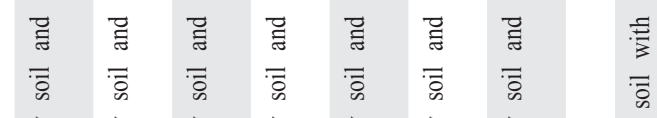

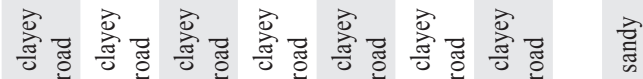

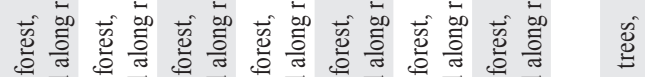

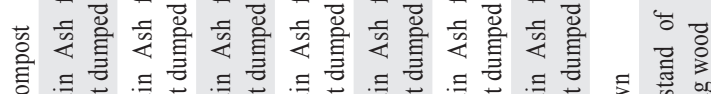

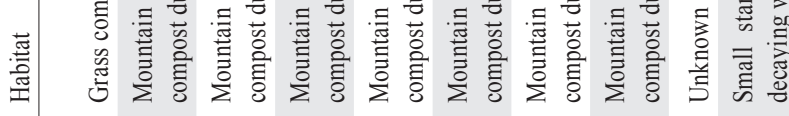

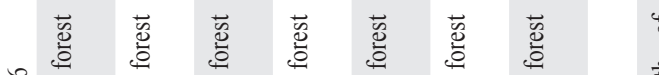

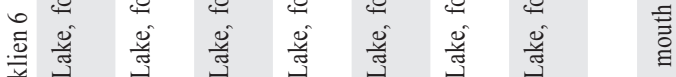

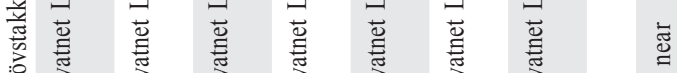

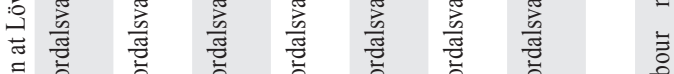

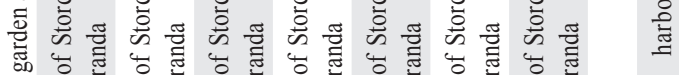

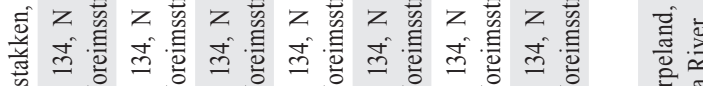

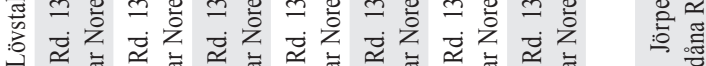

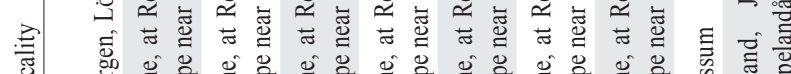

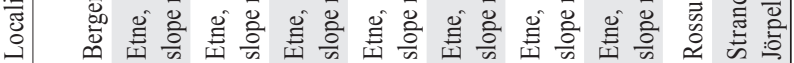

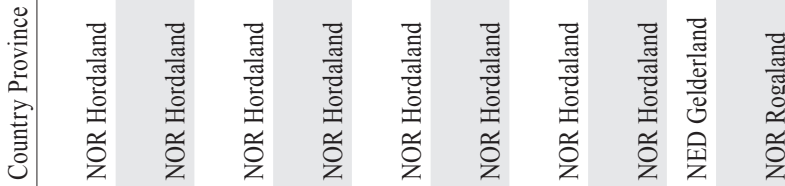

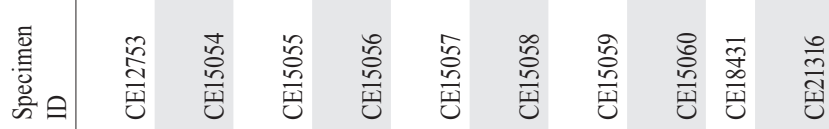

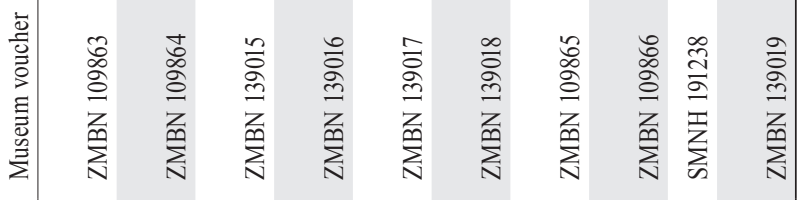

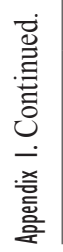

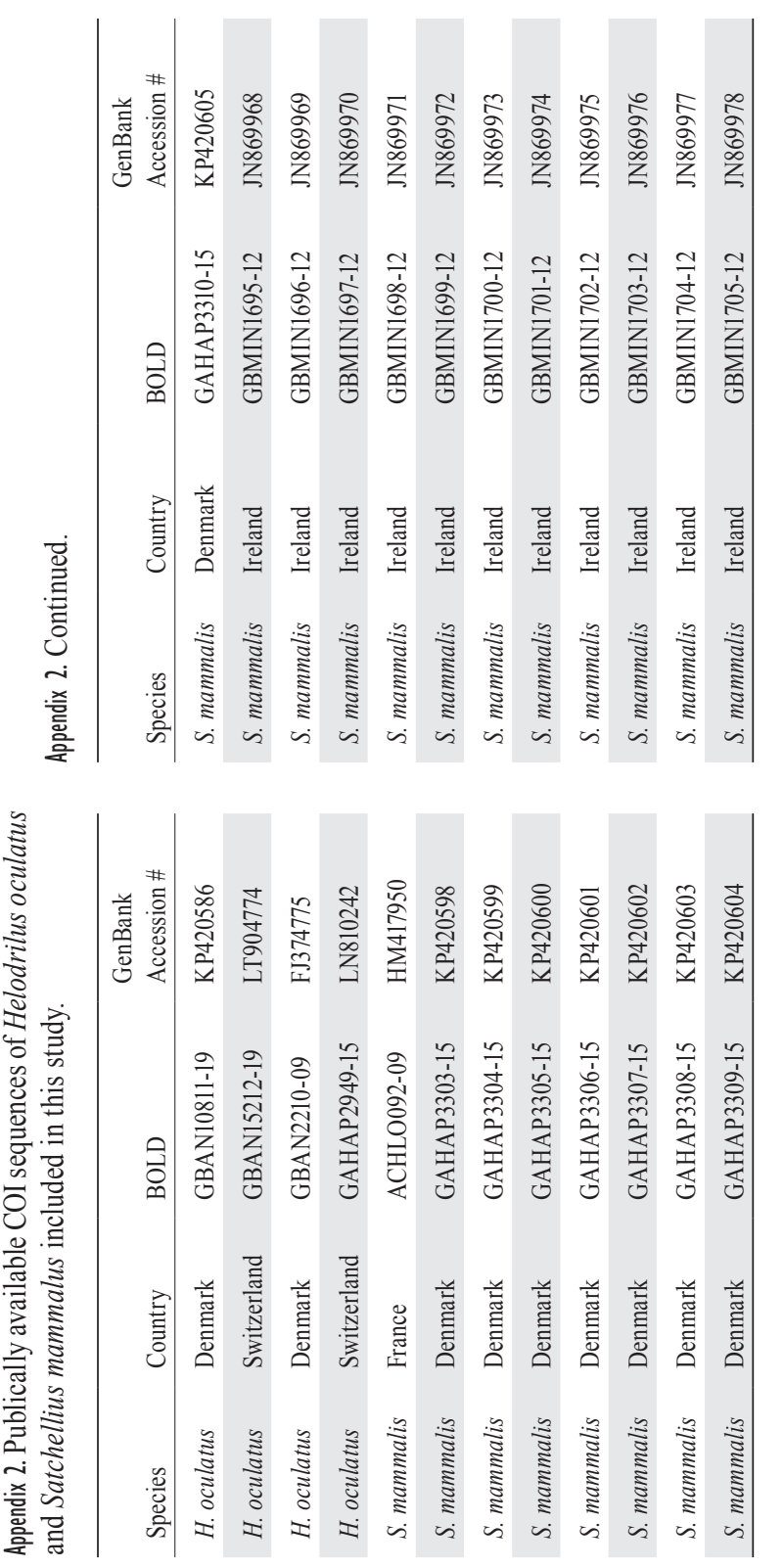




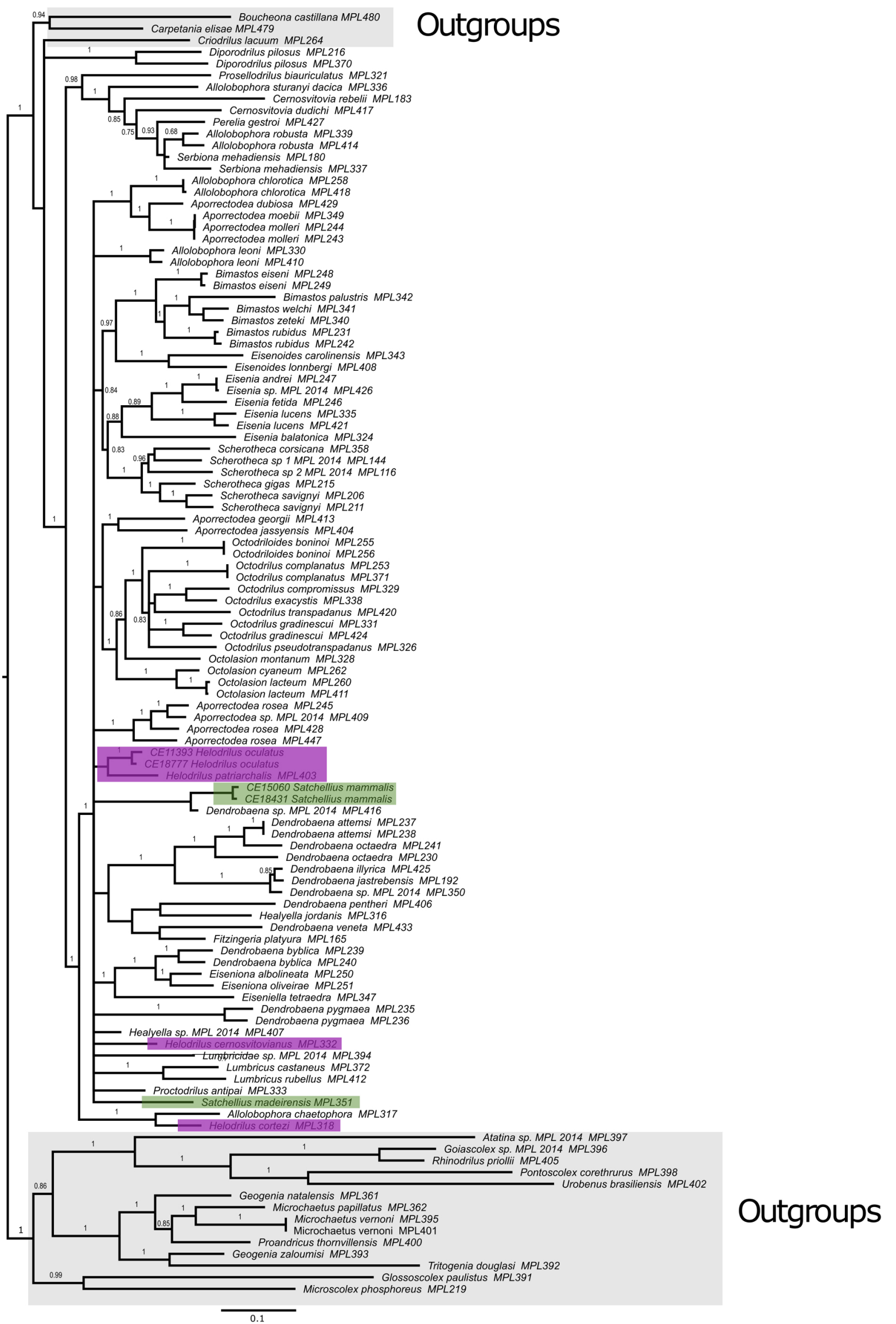

Appendix 3. Lumbricidae phylogeny based on data from Domínguez et al. (2015) and newly produced sequences from Helodrilus oculatus and Satchellius mammalis. The phylogeny is based on a concatenated data matrix consisting of 110 specimens and it is $5,188 \mathrm{bp}$ long. The phylogeny is estimated using BI in MrBayes. Numbers at branches are posterior probabilities, only values $>0.75$ are shown. Scale shows expected number of changes per site. 